https://doi.org/10.15407/ufm.22.02.204

\author{
D.A. ROMANOV*, V.V. POCHETUKHA, \\ V.E. GROMOV**, and K.V. SOSNIN \\ Siberian State Industrial University, \\ 42 Kirov Str., 654007 Novokuznetsk, Russian Federation \\ *romanov_da@physics.sibsiu.ru,**gromov@physics.sibsiu.ru
}

\title{
FUNDAMENTAL RESEARCH ON THE STRUCTURE AND PROPERTIES OF ELECTROEROSION- RESISTANT COATINGS ON COPPER
}

\begin{abstract}
The electroerosion-resistant coatings of $\mathrm{CuO}-\mathrm{Ag}$ and $\mathrm{ZnO}-\mathrm{Ag}$ systems were obtained on the $\mathrm{Cu}$ surface. Formation of coating was caused by the processing of copper surface with plasma formed in electrical explosion of silver foil with weighed sample of copper oxide or zinc oxide. After electroexplosion spraying, the electron-beam treatment of coatings was performed. The nanohardness, Young modulus, wear resistance, friction coefficient, and electrical erosion resistance of the formed coatings were studied. All studied properties exceed those of copper. Electrical erosion coatings were studied by the methods of scanning electron microscopy, transmission electron microscopy, and atomic force microscopy. It became possible to achieve the high level of operational properties of electrical erosion coatings due to their nanostructurization. Structure of coating is formed by cells of high-speed crystallization. The size of cells varies within the range from $150 \mathrm{~nm}$ to $400 \mathrm{~nm}$. The cells are separated by interlayers of the second phase whose thickness varies as 15$50 \mathrm{~nm}$. By method of atomic force microscopy, the separate particles of $\mathrm{ZnO}$ or $\mathrm{CuO}$ of different shapes and 10-15 $\mathrm{nm}$ in size chaotically located in silver matrix were revealed as well as spherical particles of $\mathrm{ZnO}$ or $\mathrm{CuO}$ in size of $2-5 \mathrm{~nm}$. The total thickness of coatings is $60 \mu \mathrm{m}$. The complex of studies we have carried out permits to recommend the integrated processing for strengthening the switch copper contacts of powerful electrical networks.
\end{abstract}

Keywords: composite coating, $\mathrm{CuO}-\mathrm{Ag}, \mathrm{ZnO}-\mathrm{Ag}$, copper contact wires, electron beam processing, electroexplosion spraying, erosion resistant, nanostructurization.

Citation: D.A. Romanov, V.V. Pochetukha, V.E. Gromov, and K.V. Sosnin, Fundamental Research on the Structure and Properties of Electroerosion-Resistant Coatings on Copper, Progress in Physics of Metals, 22, No. 2: 204-249 (2021) 


\section{Introduction}

The touch of the electrical contacts takes place along not the entire surface but only in separate points due to the roughness on the surface of the contact [1-3]. In practice, the touch of their contact surfaces always occurs along small areas [4-6] independent of the electrical contact type. This is because the surface of the contact elements cannot be ideally even [4]. Therefore, practically, on the approaching of the contact surfaces, at first, some projecting peaks (points) come into contact and then, as the pressure increases, the deformation of the contact materials takes place, and these points transform into small areas [7-9]. The lines of the electric current, when passing from one contact to another, gather to these points of the touch $[10,11]$. Therefore, the contact introduces some additional contact resistance into the circuit commutated by it. The transient resistance $[12,13]$ is one of the main parameters of the electrical contacts' quality because it characterizes the quantity of energy being absorbed in the contact connection, which transforms into heat and heats up the contact.

$M A X$ phases with formula $M_{n+1} A X_{n}$ (where $M$ is a transition metal, $A$ is element of group III or IV, $X$ is C and/or N, $n=1-3$ ) are a group of layered ternary compounds possessing high elastic modulus as well as a good thermal and electrical conductivity combining the properties of both metals and ceramics [14]. As typical $M A X$ phases, $\mathrm{Ti}_{3} \mathrm{AlC}_{2}$ [15] and $\mathrm{Ti}_{3} \mathrm{SiC}_{2}$ [16] strengthen well the electrical contact materials based on copper. Prof. M. Liu and co-authors [17] fabricated $\mathrm{Ag} / \mathrm{Ti}_{3} \mathrm{AlC}_{2}$ composites by hot pressing and found that they were potentially suitable for materials of sliding electrical contacts and might be used with high efficiency because they showed good mechanical and electrical properties. In the work [18], the authors prepared $\mathrm{Ag} / 10$ mas. $\% \mathrm{Ti}_{3} \mathrm{AlC}_{2}$ electrical contact material by the method of powder metallurgy and studied its arc erosion resistance that appeared to be comparable with commercial contacts $\mathrm{Ag} / \mathrm{CdO}$ being used in contactors. As a rule, a grain size of matrix phase and filler size are of considerable importance for mechanical and electrical properties of the composite.

For example, Prof. H. Li et al. [19] reported that finer reinforcing particles of $\mathrm{TiB}_{2}$ and $\mathrm{SnO}_{2}$ are more advantageous for smaller loss of mass and relative mass transfer of silver substrate of electrical contact material during tests for arc electrical erosion. However, Prof. N. Ray et al. $[20,21]$ informed that electrical contact resistance and electrical erosion resistance of $\mathrm{Ag} / \mathrm{WC}$ electrical contact material decreased with the increase in WC particle size. In addition, graphite structural anisotropy is reported to affect the electrical conductivity and arc erosion resistance of silver-graphite electrical contact materials [22, 23]. According to the authors' information, the effect of silver grain size, par- 
ticle size, and equalizing $M A X$ phases in $\mathrm{Ag} / M A X$ properties in electrical contact material were not reported. The methods of power metallurgy followed by extrusion, drawing and rolling were used for manufacturing $\mathrm{Ag} / \mathrm{C}$ [24], $\mathrm{Ag} / \mathrm{SnO}_{2}$ [25], $\mathrm{Ag} / \mathrm{CdO}$ [26], $\mathrm{Ag} / \mathrm{ZnO}$ [26] electrical contact materials. However, the processes change in sample size and/or the requirements concerning high temperature deformation and pressure.

Equal channel angular pressing (ECAP) was used in Refs. [27-29] for preparation of $\mathrm{Ag} / \mathrm{Ti}_{3} \mathrm{AlC}_{2}$ electrical contact materials. The composite $\mathrm{Ag} / 10$ mass. $\% \mathrm{TiAlC}_{2}$ with $\mathbf{9 9 . 8} \%$ relative density and homogeneous microstructure was manufactured by the ECAP method at a relatively low temperature of $200{ }^{\circ} \mathrm{C}$ and pressure of $37 \mathrm{MPa}$. The $\mathrm{Ti}_{3} \mathrm{AlC}_{2}$ particles separated into layers and equalized mainly in $\mathrm{Ag}$ matrix after ECAP. Advantageous equalizing of $\mathrm{Ti}_{3} \mathrm{AlC}_{2}$ resulted in anisotropy of electrical and compressing properties and arc erosion resistance of the composite. The properties of sintered compacted and ECAP sample were investigated. The Vickers hardness of ECAP sample was $\approx 1.5$ times higher than that in sintered pressed material. The ECAP sample has the least specific resistance of $59.3 \cdot 10^{-9} \mathrm{Ohm} \cdot \mathrm{m}$. The maximum compression strength and deformation amounted to $805 \pm 18.6 \mathrm{MPa}$ and $43.8 \pm 2.2 \%$ in ECAP sample loaded perpendicular to $\mathrm{Ti}_{3} \mathrm{AlC}_{2}$ equalization. The ECAP sample with surface parallel to $\mathrm{Ti}_{3} \mathrm{AlC}_{2}$ centring showed a better stability to arc erosion. Mechanism being responsible for anisotropic microstructure and properties were proposed and discussed.

Fine-grained $\mathrm{Cu}(70-90 \%)-\mathrm{W}$ composites were successfully manufactured [30-32] using $\mathrm{Cu} / \mathrm{W}$ nanosize powders in conditions of vacuum. Sintering process of $\mathrm{Cu} / \mathrm{W}$ composites is explained by interactions as a result of sintering that occur both inside the powders and between powders. Microstructural analysis of $\mathrm{Cu} / \mathrm{W}$ powders showed that coarse spherical and nanosize particles of tungsten were evenly introduced into copper matrix. The $\mathrm{Cu} / \mathrm{W}$ interface has semi-coherent bond and shows a good contact. The relative density, hardness, electrical conductivity and crystal dimension of tungsten in $\mathrm{Cu} / \mathrm{W}$ composites increased when sintering temperature increased from 1000 to $1090{ }^{\circ} \mathrm{C}$. It was detected that, with the increase in copper content, the hardness and tungsten grain size of $\mathrm{Cu} / \mathrm{W}$ composites decrease but relative density and electrical conductivity improve. The tungsten relation of electrical conductivity, sintering temperature and crystal size of $\mathrm{Cu} / \mathrm{W}$ composites was described by means of regressive formula.

For $\mathrm{Cu}-\mathrm{Ag}$ film contact [33-35], the good boundary properties of the layer allow the sliding with a low friction coefficient, polished wornout surface and high bearing capacity. In conditions of current load, the mechanical breaking and repeated touching of contact surface result in electric arc formation, and damage of $\mathrm{Ag}$ film induced by electric arc 
depends on polarity of pin and disc. For positive $\mathrm{Cu}$ pin on disc with $\mathrm{Ag}$ negative film, the rainbow film and transparent LP108 on Ag film are observed. While for negative $\mathrm{Cu}$ pin on disc of $\mathrm{Ag}$ positive film, the removal of $\mathrm{Ag}$ film is observed, and it results in obtaining the suspension of Ag dark ionic liquid. In both cases, LP108 is not worsened by electric arc. The damage induced by electric arc on Ag film may be removed by providing accurate correspondence of contact surface.

The three-dimensional continuous composite materials based on Agmatrix, reinforced by Ni-network, were manufactured by hot pressing of $\mathrm{Ag}-\mathrm{Ni}$ composite powders with Ni-powders applied on surface of $\mathrm{Ag}$ grains [36-38]. Formation of $3 D$ continuous Ni network increases in load transmitted from Ag matrix to second phase $\mathrm{Ni}$ causing $\mathrm{Ag}$ and $\mathrm{Ni}$ deformation during deformation stretching. Combined deformation begins as rotation of orientation, e.g., Ag matrix displaces to $\{111\}\langle\mathbf{1} \overline{1} 0\rangle$, twins to $\{111\}\langle\mathbf{1 1 2}\rangle$ and $\langle 100\rangle$ that results to texture formation during $\mathrm{Ni}$ second phase along definite direction. Finally, continuous three-dimensional nickel networks were broken and stretched into belts being parallel to axial direction of composite wire. The increase in real deformation may increase in Ni electric networks' length in axial direction, thus, increasing hardness and electroconductivity of $\mathrm{Ag}-\mathrm{Ni}$ materials for electrical contacts. Furthermore, two-dimensional characteristics of electric networks with high profile of resistance increase in hydraulic resistance of melted Ag. Therefore, the Ag-Ni belt-reinforced materials for electrical contacts demonstrate low loss of mass after 100000 on/off cycles (1.8 $\mathrm{mg}$, total $22.8 \%$ of sample mass reinforced with spheroidal fibres).

The $\mathrm{Al}_{2} \mathrm{O}_{3}-\mathrm{Cu} / 25 \mathrm{~W}_{5} \mathrm{Cr}$ and $\mathrm{Al}_{2} \mathrm{O}_{3}-\mathrm{Cu} / 35 \mathrm{~W}_{5} \mathrm{Cr}$ composites were manufactured by the methods of vacuum hot pressing and internal oxidation [39-41]. The electrical conductivity, relative density and Brinell hardness were measured. The effect of nano- $\mathrm{Al}_{2} \mathrm{O}_{3}-\mathrm{Cu} /(\mathrm{W}, \mathrm{Cr})$ composites was studied by means of tests for isothermal compression using thermomechanical imitator Gleeble-1500D in temperature range from 650 to $950{ }^{\circ} \mathrm{C}$ and deformation rate of $0.001^{-10} \mathrm{~s}^{-1}$. The deformed microstructure was characterized and analysed with optical and transmission electron microscopy. The interaction of quenching process, dynamic recovery and dynamic recrystallization was illustrated. As shown, the $\mathrm{Cr}$ particles were extruded into tapes, and $\mathrm{W}$ particles underwent small deformation during hot compression. Besides, the composite with higher tungsten content had a higher flow stress. Particles of nano- $\mathrm{Al}_{2} \mathrm{O}_{3}$ pinned dislocations and inhibited dynamic recovery and dynamic recrystallization. In addition, material is still at the stage of subcrystals' formation at $850{ }^{\circ} \mathrm{C}, 0.01 \mathrm{~s}^{-1}$. Consequently, the $\mathrm{Al}_{2} \mathrm{O}_{3}-\mathrm{Cu} / 35 \mathrm{~W}_{5} \mathrm{Cr}$ composite has typical characteristics of dynamic recovery. Therefore, the $\mathrm{Al}_{2} \mathrm{O}_{3}-\mathrm{Cu} /(\mathrm{W}, \mathrm{Cr})$ composites demonstrate good characteristics at high temperatures. 
The tungsten-copper $(\mathrm{W}-\mathrm{Cu})$ contact materials are the main components of high-voltage electrical switchers. However, a considerable effect of arc ablation at high voltage and high current often result in breaking the connection and mechanical losses that affect seriously a safe operation of apparatuses. In the studies [42-44], the failure mechanism of tungsten and copper contact materials caused by considerable arc ablation in atmosphere of sulphur hexafluoride $\left(\mathrm{SF}_{6}\right)$ were investigated. The results showed that arc ablation of contact material was mainly caused by vaporization and splashing a copper component having a low melting temperature, followed by ablation and splitting off the tungsten (W) skeleton structure. Taken together, it increased in surface roughness of contact material and then accelerated still grater the volatilization of copper component and reaction between material components and arc-quenching medium $\mathrm{SF}_{6}$. Finally, contact materials lost their functions of arc-quenching and current switching. Modelling experimental work was carried out, and it confirmed the failure mechanisms of contact materials de-scribed above. Due to instantaneous high temperature and high voltage arising during arc, the $\mathrm{Cu}$ and $\mathrm{W}$ phases in $\mathrm{W}-\mathrm{Cu}$ alloy underwent considerable vaporization and mass loss.

In articles [45-47], the main attention is paid to wear, friction and electrical characteristics of recently developed design of disc contact for sliding electrical contacts. Different types of graphite and copper as material combinations, various working parameters of contact and, in particular, different directions of electric current that is disc polarity were studied in real condition of contact on special tribological test machine. Electrographite and polymer-bonded graphite worked in pair contact compared to copper and with each other. Pair of polymer-bonded graphite/polymer-bonded graphite showed better results almost for all parameters tested while mixed heterogeneous combination of polymerboded graphite/electrographite had the worse characteristics. In addition, all pairs containing electrographite material demonstrated unstable contact behaviour and as a whole, gave worse common characteristics. Wear of matched pairs of graphite was less than that of graphite/ copper pairs. Effect of polarity on graphite/graphite material combination was negligible while in graphite/copper combination it was found that electric current direction had a considerable effect on discs wear. Wear of positive graphite disc was $30 \%$ lower than in negative graphite disc while wear of positive copper disc was 8 times greater than that in negative copper disc. Differences in boundary contact film were observed in graphite/copper contacts depending on surface polarity that means that sliding contacts with electric current, flowing from graphite disc to copper one, demonstrated less wear than contacts wherein current flows from copper to graphite disc. 
The copper-base materials are widely used industrial products employed extensively in the fields of power metallurgy, electrical contacts, heat exchangers, etc. However, ease in surface oxidation limits a durability and effectiveness of components based on copper. The authors [48-50] developed the process of powder metallurgy for manufacturing graphene/copper composites using copper powders that first were applied on graphene layers by thermal chemical vapour deposition (CVD). The graphene/copper composites enclosed in graphene-bonded network then could be manufactured by vacuum hot pressing. After thermal oxidation (to $220^{\circ} \mathrm{C}$ ) in wet air for several hours, the authors discovered that surface oxidation degree of samples was far less than in their pure analogue $\mathrm{Cu}$, and samples [48-50] showed less increase in contact resistance of interface when in use as electrical contact materials. As a result, graphene/copper composites demonstrated a considerable improvement in capability to oxidation resistance (by $\approx 5.6$ times) compared to their analogue of pure copper, thus suggesting a potential application as new materials for electrical contacts.

The $\mathrm{Cu} / \mathrm{Ni}-\mathrm{P} / \mathrm{Au}$ multilayer systems [51-53] are used as electrical contacts. The $\mathrm{Au}$ upper layer is thin and porous. The pores deliver corrosion medium to lower layer that induces corrosion by means of galvanic connecting mechanism. Therefore, filling the pores is necessary to increase in the service life of electronic devices. The pores may be hermetically sealed by electrodeposition of polymethyl methacrylate that decreases in porosity index $(\approx 97 \%)$ and increases in corrosion resistance (by $\approx 10$ times) of electrical contacts after 10 cycles of electropolymerization. However, nonuniform polymer film was formed at a larger number of polymerization cycles $(>50)$ that decreased in corrosion resistance.

The method of processing (treatment) of the contact surfaces and their state $[54,55]$ may strongly affect the transient resistance. Nowadays, it is proved by the scientists of different countries that the application of electron beam processing (EBP) enables to obtain a mirrorsmooth surface of the materials [56], nanostructurize [57] and homogenize the material [58]. The application of electron-beam treatment (EBT) permits the increase in different service properties of the materials [59]. Knowing this information about EBT it seems to be effective to use the technology for the processing of the surface of electrical contacts [60]. In particular, it will make possible to minimize the transient resistance of the electrical contacts and to increase in the service life of their operation.

In this work, we review, study and analyse the EBP effect on the structure and morphology of the phases of the electroexplosion coating of $\mathrm{CuO}-\mathrm{Ag}$ and $\mathrm{ZnO}-\mathrm{Ag}$ systems via the scanning electron microscopy, transmission electron microscopy, and x-ray phase analysis. In addition, we carry out the tests for electroerosion resistance, wear resistance, nanohardness, and Young modulus. 


\section{Material and Methods of Investigation}

The samples that were sprayed were copper plates with sizes of $20 \times 20 \times$ $\times 3 \mathrm{~mm}$. For the electroexplosive spraying (EES), the main processing parameters are the pulse time $\tau$ and the absorbed power density $q=$ $=5.5 \mathrm{GW} / \mathrm{m}^{2}$ under thermal exposure of the irradiated surface, as well as the pressure $p=12.5 \mathrm{MPa}$ of the plasma in the shock-compressed layer, which is formed near the surface. The necessary conditions for the implementation of the EES were set by the magnitude of the charging voltage of the energy accelerator storage device, the diameter of the nozzle channel and the distance from its cut to the sample, which were $1.8 \mathrm{kV}, 20$ and $20 \mathrm{~mm}$, respectively. To justify the choice of $q$ values used in the processing, the temperature of the irradiated surface was calculated using the model of heating with a flat heat source [61].

In the work, composite coatings with a filled structure were formed. The composite filled structure is formed by a metal matrix, which is hardened by its high-strength fine dispersed refractory particles insoluble in it.

Coatings were formed at the absorbed power density value, which ensured the premelting state of the treatment surface (Table 1). The EBT of electroerosion-resistant coatings of all systems was performed in the modes with the number of pulses 10 , pulse time $100 \mu \mathrm{s}$, with a variable surface energy density of $45,50,55$, and $60 \mathrm{~J} / \mathrm{cm}^{2}$ and with the number of pulses 20, pulse time $200 \mu$ s, and surface energy density $60 \mathrm{~J} / \mathrm{cm}^{2}$ (Table 1).

Sections for metallographic studies were prepared as follows: samples were cut out on an automatic cutting machine with a diamond wheel,

Table 1. Parameters for coating formations

\begin{tabular}{|c|c|c|c|c|c|}
\hline \multirow{3}{*}{ Coating } & \multicolumn{4}{|c|}{ Electroexplosive spraying parameters } & \multicolumn{3}{|c|}{ Electron beam treatment parameters } \\
\cline { 2 - 6 } & $q, \mathrm{GW} / \mathrm{m}^{2}$ & $m, \mathrm{mg}$ & $E_{s}, \mathrm{~J} / \mathrm{cm}^{2}$ & $t, \mu \mathrm{s}$ & $N$, pulses \\
\hline \multirow{2}{*}{$\mathrm{CuO}-\mathrm{Ag}$} & \multirow{2}{*}{5.5} & $50 \times 250$ & 45 & 100 & 10 \\
& & & 50 & 100 & 10 \\
& & & 55 & 100 & 10 \\
& & & 60 & 100 & 10 \\
& & & 60 & 200 & 20 \\
\cline { 3 - 6 } $\mathrm{ZnO}-\mathrm{Ag}$ & \multirow{2}{*}{$* 0 \times 250$} & 45 & 100 & 10 \\
& & & 50 & 100 & 10 \\
& & & 55 & 100 & 10 \\
& & & 60 & 100 & 10 \\
& & & 60 & 200 & 20 \\
\hline
\end{tabular}

Note: $q$ - absorbed power density; $m$ - sample mass; $E_{s}$ - surface energy density; $t$ - pulse duration; $N$ - number of pulses; pulse repetition frequency is $0.3 \mathrm{~Hz}$ ) 
and then, they were ground, polished and chemically etched. The preparation of thin sections for metallographic investigations in the general case included cutting samples on a cutting machine with a diamond wheel, grinding, polishing, and chemical etching. Before grinding, the samples were fixed in a mandrel and filled with epoxy resin. Grinding was carried out with emery papers with decreasing dispersion of abrasive particles. The quality of grinding was controlled under a microscope at a magnification of 50-100 times. After grinding on the papers, polishing was carried out with chromium oxide powder on the cloth. Before microscopic inspection, with an increase of 200-400 times, the sections were thoroughly washed. Polishing was completed when visible traces of machining were eliminated, and additional processing did not increase the quantity and clarity of the details of the structure observed on the thin section.

Chemical etching of the sections was carried out with a solution of the following composition: $\mathrm{HCl}-2.5 \mathrm{ml}, \mathrm{FeCl}_{3}-3 \mathrm{~g}, \mathrm{C}_{2} \mathrm{H}_{5} \mathrm{OH}-100 \mathrm{ml}$. The etching time ranged from 3 to $5 \mathrm{~s}$. After etching, the samples were thoroughly washed in running water and ethanol, and then dried. The mass of the components was monitored using a Shimadzu AUX 120 analytical balance. To measure the thickness of the coatings, the sizes of the structural components, to study the phase distribution in depth, and photograph the sections, we used the Carl Zeiss Axio Observer A1m metallographic microscope. This device allows one to get an image of small objects and their details at various magnifications up to 2000 times. The surface structure of the samples and thin sections was studied by scanning electron microscopy using Carl Zeiss EVO50 and Phillips SEM 515 devices with EDS X-Act and EDAX energy dispersive x-ray spectral analysis attachments according to the methods described in Refs. [62, 63]. The analysis of the defective substructure and phase composition of the surface layer of the coating melting upon EBT was carried out by transmission electron diffraction microscopy (EM-125 device). Foils were made of plates located at a distance of $25-30 \mu \mathrm{m}$ from the irradiation surface and cut parallel to the surface of the coating. X-ray diffraction analysis was performed on the ARLX'TRA diffractometer in copper radiation with a wavelength of $\lambda_{\alpha}=0.15406 \mathrm{~nm}$. In addition, coatings were investigated by atomic force microscopy (Solver NEXT device).

The tribological properties (friction coefficient and wear resistance) of the coatings were studied in the geometry of a disk pin using a TNTS-AX0000 tribometer (CSEM, Switzerland) at a temperature of $25^{\circ} \mathrm{C}$. A VK-8 hard alloy ball with a diameter of $3 \mathrm{~mm}$ was used as a counterbody, the track diameter was $6 \mathrm{~mm}$, the rotation speed was $2.5 \mathrm{~cm} / \mathrm{s}$, the load was $3 \mathrm{~N}$, the distance to stop was $38.6 \mathrm{~m}$, and the number of revolutions was 3000 . The wear criterion was the specific volume of the 
material wear track, which was determined using a MicroMeasure 3D Station laser optical profilometer and calculated by the formula:

$$
V=\frac{2 \pi R A}{F L},
$$

where $R$ is the radius of the track, $A$ is the cross-sectional area of the wear groove, $F$ is the magnitude of the applied load, $L$ is the distance travelled by the ball.

Tests for the electrical discharge resistance of coatings under conditions of arc erosion were carried out on the contacts of electromagnetic starters of the CJ20 grade. In accordance with the requirements of the AC-3 test mode for switching wear resistance, alternating current and inductive load were used when working in a three-phase circuit. The low voltage values were $400 / 230 \mathrm{~V}$, the frequency was $50 \mathrm{~Hz}$ for currents up to $320 \mathrm{~A}$ and $\cos \phi=0.35$ and the number of switching cycles was 6000 according to the. The number of on-off cycles to complete destruction was $\approx 8000$.

\section{Results and Discussion}

\subsection{Structure of Electroerosion-Resistant Coatings of CuO-Ag}

Using scanning electron microscopy, the structure and elemental composition of the transverse section of the coating/substrate system formed by the electric explosion method were studied. A typical image of the cross-sectional structure of the coating of the composition of $\mathrm{CuO}-\mathrm{Ag}$ is shown in Fig. 1. An analysis of the results shows that the formed coating is a composite material that is uniform in structure (Fig. 1, $a, b$ ). According to the morphology of the structure and the etching contrast, the formed coating consists of a light silver matrix and dark $\mathrm{CuO}$ inclusions with sizes varying from 0.3 to $0.5 \mu \mathrm{m}$ (Fig. 1, $b$ ). The elemental composition of the coating was analysed by x-ray spectral analysis. The research results are presented in Fig. 1, $c-d$. Analysing the results presented in Fig. 1, $c-d$, it can be noted that the concentrations of copper (Fig. 1, c), oxygen (Fig. 1, $d$ ) and silver (Fig. 1,e) in the coating vary slightly in thickness. This fact also indicates the structural homogeneity of the resulting coating.

Atomic force microscopy was carried out in a coating layer located at a distance of $10 \mu \mathrm{m}$ (Fig. 2) from the coating surface as well as at the interface between the coating and the copper substrate (Fig. 3). Since the electroexplosive coating (EEC) is formed by a silver matrix, and particles of $\mathrm{CuO}$ powder located in it, small particles of $\mathrm{CuO}$ powder can be crumbled from the matrix at the preparation of a thin section.

In this case, pores are formed at the place of the precipitated particles (dark areas in Fig. $2 a, b$ ) with a depth of 30 to $100 \mathrm{~nm}$ and a width 


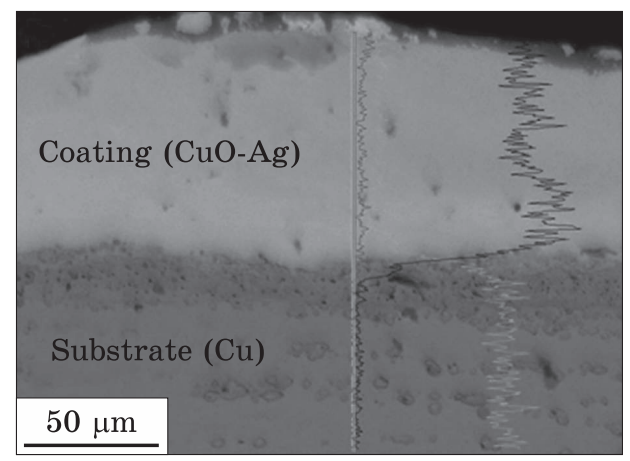

$a$
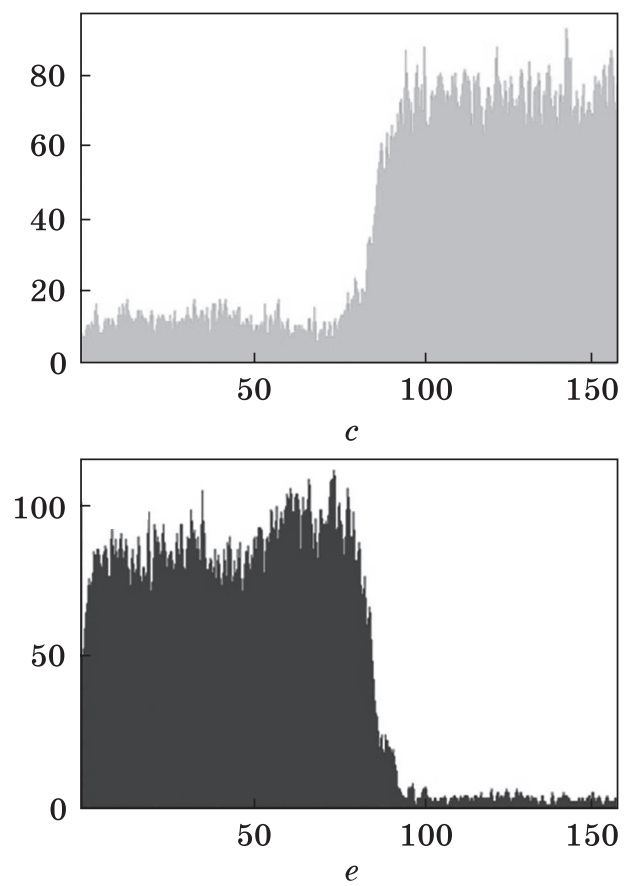

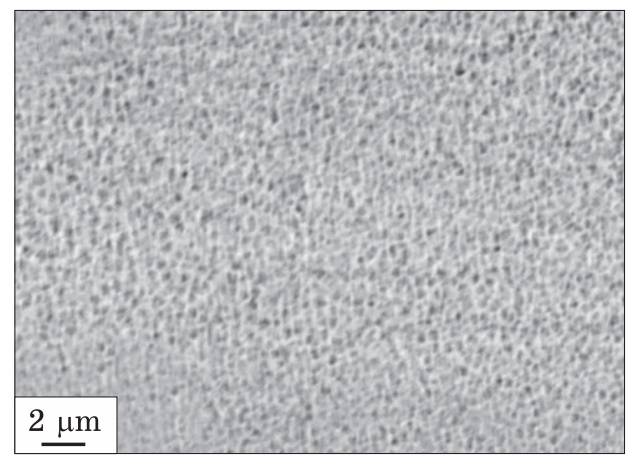

$b$

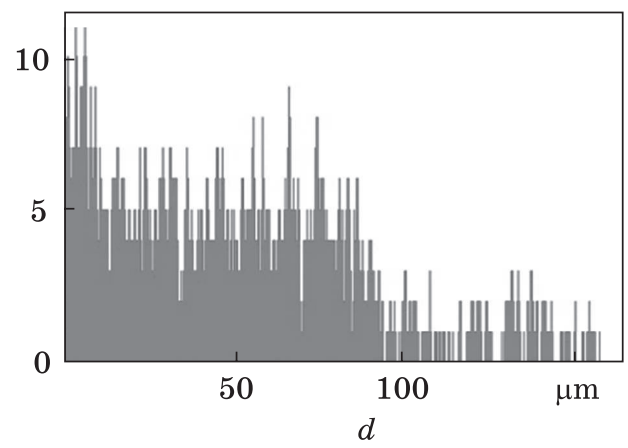

Fig. 1. Structure of the electric explosion coating of $\mathrm{CuO}-\mathrm{Ag}$ [60]. Atomic content of elements are determined along the line indicated on $a$. Here, $a-$ general view of the coating; $b-$ composite filled structure; $c$ and $d-$ concentration profiles of $\mathrm{Cu}, \mathrm{O}$, and $\mathrm{Ag}$ atoms, respectively. $\mathrm{Cu}$ concentration determined by characteristic $\mathrm{x}$-ray ra-

diation $K_{\alpha 1}$; O concentration - according to $L_{\alpha 1}$. See also Fig. 4 in [D. Romanov et al., J. Mater. Res. Technol., 8, No. 6: 5515 (2019)]; https://doi.org/10.1016/j. jmrt.2019.09.019

of 2 to $5 \mathrm{~nm}$ (Fig. 2, c). Particles of $\mathrm{CuO}$ are dispersed up to $2-5 \mathrm{~nm}$ during an electric explosion in the course of the formation of a pulsed plasma jet of products of an electric explosion of conductors.

Separate large particles of various shapes with sizes from 10 to $15 \mathrm{~nm}$ are also detected. These $\mathrm{CuO}$ particles do not crumble from the silver matrix when preparing the thin section, they are sharply highlighted in colour (they are lighter in comparison with the matrix). They are randomly arranged in a silver matrix. As can be seen from Fig. 2, $a, b$, 

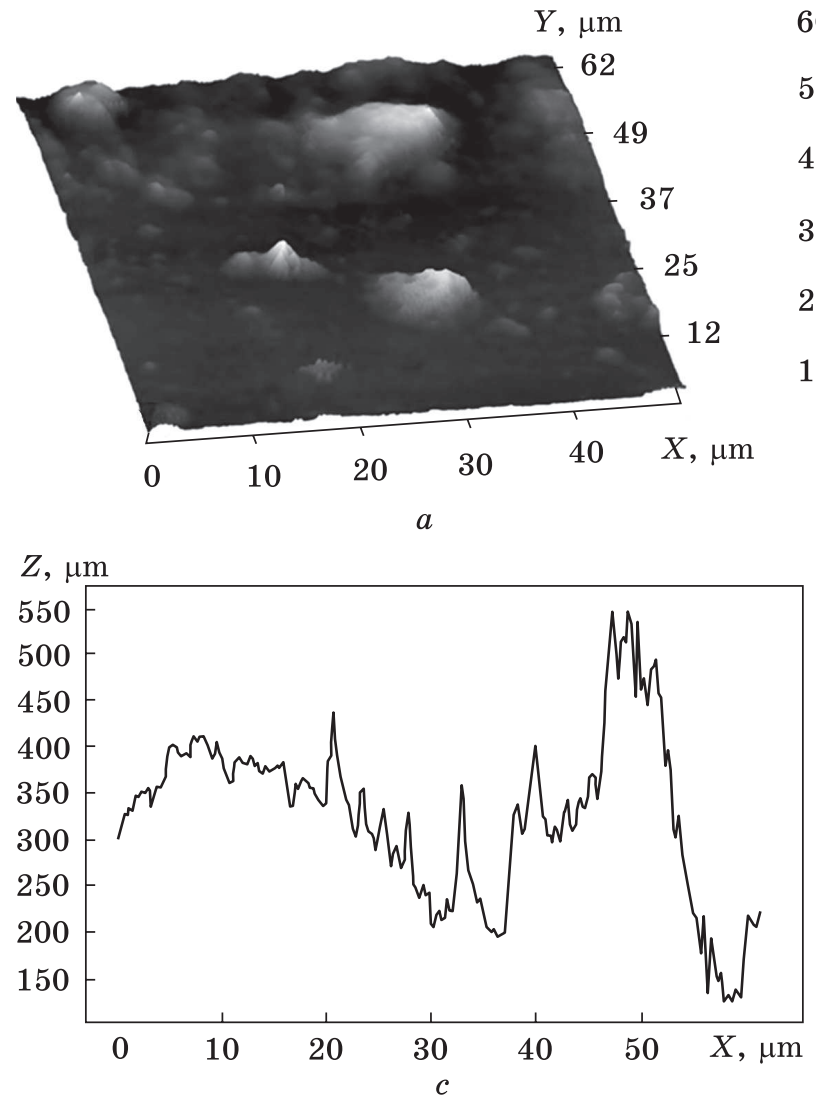

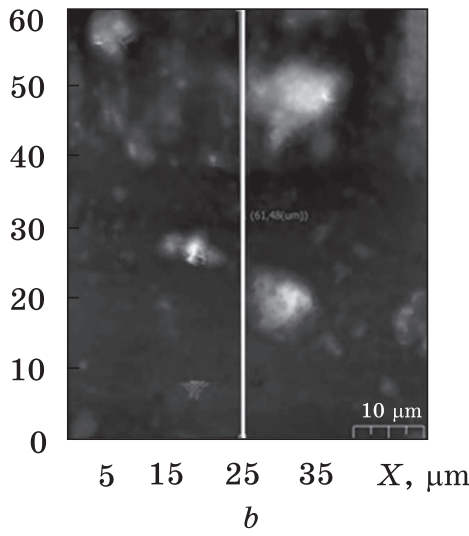

Fig. 2. Atomic force microscopy identified coating structure of $\mathrm{CuO}-\mathrm{Ag}$ system (see also Fig. 2 in Ref. [60]). Here, $a$ - distribution of the relief unevenness (perspective view); $b-$ position of the secant (top view); $c-$ distribution of the roughness along the base length

large particles have a complex structure the characteristic structural units of which they are composed are spheres (globules) with a diameter of 2 to $5 \mathrm{~nm}$ (these are small spherical particles described above). The ratio of the silver matrix, large and small particles of $\mathrm{CuO}$ powder is 0.6-0.15-0.25. If we take into account that large particles of $\mathrm{CuO}$ consist of smaller globular particles of $\mathrm{CuO}$, then, the ratio of silver matrix and inclusions of $\mathrm{CuO}$ powder is $\mathbf{0 . 6 - 0 . 4}$. This ratio is proportional to the content of $\mathrm{CuO}$ powder and silver foil used for electric explosion spraying. The average surface roughness of the coating surface of the $\mathrm{CuO}-\mathrm{Ag}$ system is $100 \mathrm{~nm}$. Thus, it was possible to identify an important structural element - the $\mathrm{CuO}$ globule, a spherical particle with a diameter of 2 to $5 \mathrm{~nm}$. There is a multilevel hierarchical structure of the coating of the $\mathrm{CuO}-\mathrm{Ag}$ system based on the same type of spherical $\mathrm{CuO}$ particles with a diameter of 2 to $5 \mathrm{~nm}$. The single structural unit of which the $\mathrm{CuO}$ inclusions located in the silver matrix consist of is a very important argument in favour of the fractal mechanism for the formation of an electric explosive coating. Such particles constitute the first hierarchical level of the structure of the electroexplosive coating of the 


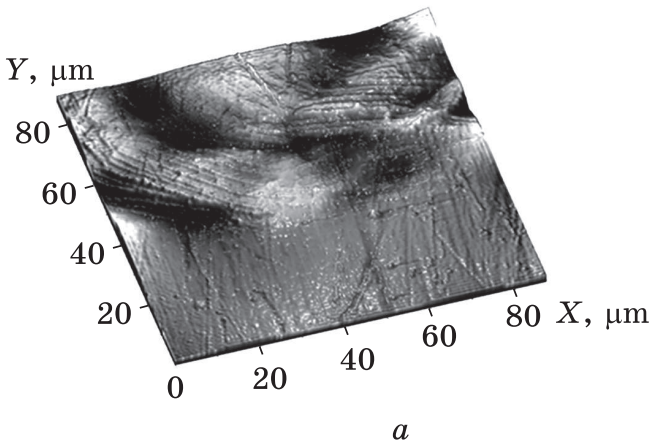

$Z, \mu \mathrm{m}$

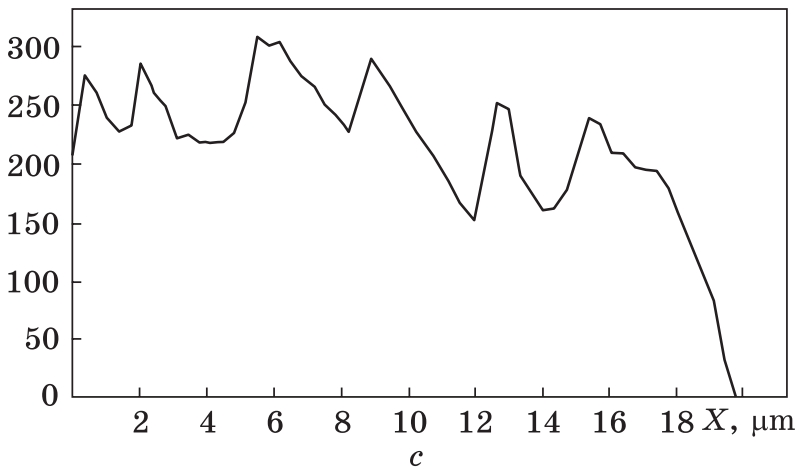

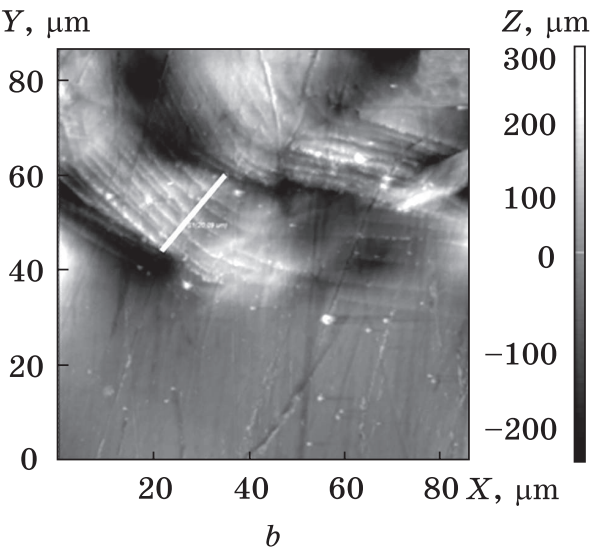

Fig. 3. The structure at the boundary of $\mathrm{CuO}-\mathrm{Ag}$ coating with the $\mathrm{Cu}$ substrate, revealed by atomic force microscopy (see Fig. 3 in Ref. [60]). Here, $a-$ the surface relief distribution (perspective view); $b$ - position of the secant line (top view); $c-$ distribution of the roughness along the basic line

$\mathrm{CuO}-\mathrm{Ag}$ system. The second hierarchical level consists of large particles of various shapes globules with sizes from 10 to $15 \mathrm{~nm}$, which, in turn, form sediment of irregularly shaped micron particles, detected by scanning electron microscopy.

At the interface between the coating and the copper substrate (Fig. 3, $a, b)$, dark depressions from 10 to $15 \mathrm{~nm}$ in size are distinguishable. The large $\mathrm{CuO}$ particles, which were discussed above, crumbled out of them. In addition, the surface periodic structures (SPS) appear in the silver matrix at the coating/substrate interface. The secant, perpendicular to these structural formations (Fig. 3, $b, c$ ), suggests that the wavelength in them is on the average $3 \mathrm{~nm}$. The structures are the residual nanorelief of the surface.

After the end of the impact of a pulsed plasma jet of electrical explosion products of conductors on the substrate and cooling of the surface, the induced relief is fixed in the form of SPS (surface periodic structures). The specific processes of their formation can be evaporation, surface melting and displacement of the melt by excessive vapour pressure, thermocapillary phenomena and thermochemical reactions, 
thermal deformations, the appearance and development of various instabilities, such as Rayleigh-Taylor, Kelvin-Helmholtz, Marangoni [64] and others. Overall, the phenomenon is universal in nature and represents an example of self-organization in a system where initially there are no distinguished directions and structures [65]. The energy regimes for the production of SPS correspond to the heating of the material to a temperature approximately equal to the melting temperature (lower limit), but not higher than the developed evaporation temperature [65]. This mode was used for electroexplosive spraying in the present work. Surface profilometry (Fig. 3, $a$ ) showed that the roughness parameter of the electroexplosive coating of the $\mathrm{CuO}-\mathrm{Ag}$ system is $73 \mathrm{~nm}$. The maximum protrusion of the profile in this case reaches $536.85 \mathrm{~nm}$, and the depression $497.5 \mathrm{~nm}$. If we compare the roughness parameters at the interface between the electrical explosive coating and the substrate (Fig. 3) with the roughness parameter in the coating layer located at a distance of $10 \mu \mathrm{m}$ (Fig. 2), we can note that they differ by 28\%. In Figure 3, $35 \%$ of the photograph is taken by the substrate and $65 \%$ by the coating. This makes it possible to conclude that the roughness of the substrate is lower than the roughness of the coating. This is logical, since due to the inclusions of $\mathrm{CuO}$ deposited from the silver matrix, the parameter of coating roughness increases.

The assembly mechanism of such a complex multilevel $\mathrm{CdO}$ in a silver matrix can be represented as follows. The single size $r_{1}$ of spherical $\mathrm{CdO}$ particles of the first hierarchy level can be explained in terms of the model of diffusion-limited aggregation by the mechanism of diffusion-limited aggregation 'particle-cluster' [66]. The plasma components of a multiphase jet of products of electric explosion of conductors distributed in a certain effective volume over some effective space of a substrate interface of the same size are assembled into a cluster, which then turns into a sphere with a diameter of 2 to $5 \mathrm{~nm}$ [66]. It should be noted that the size of the effective volume in which the formation of blanks of spherical particles of the first level of the hierarchy would depend on the composition of the exploding conductors and temperature. The formation of $\mathrm{CdO}$ clusters occurs only at the initial stage of the action of a pulsed plasma jet on the substrate. At the next stage of growth, the particle-cluster aggregation mechanism ceases to act, but the cluster sizes increase. Growth begins at the same time and ends synchronously after the exhaustion of the presence of $\mathrm{CdO}$ in the plasma state, the clusters turn into particles of almost the same size (under the discussed conditions, these are spheres with a diameter of 2 to $5 \mathrm{~nm}$ ). Particle sizes are not large enough for gravitational forces to dominate. In other words, there is a metastable state in which spheres with diameters from 2 to $5 \mathrm{~nm}$ are maintained in suspension mainly due to Brownian motion and forces of intermolecular interaction with other compo- 

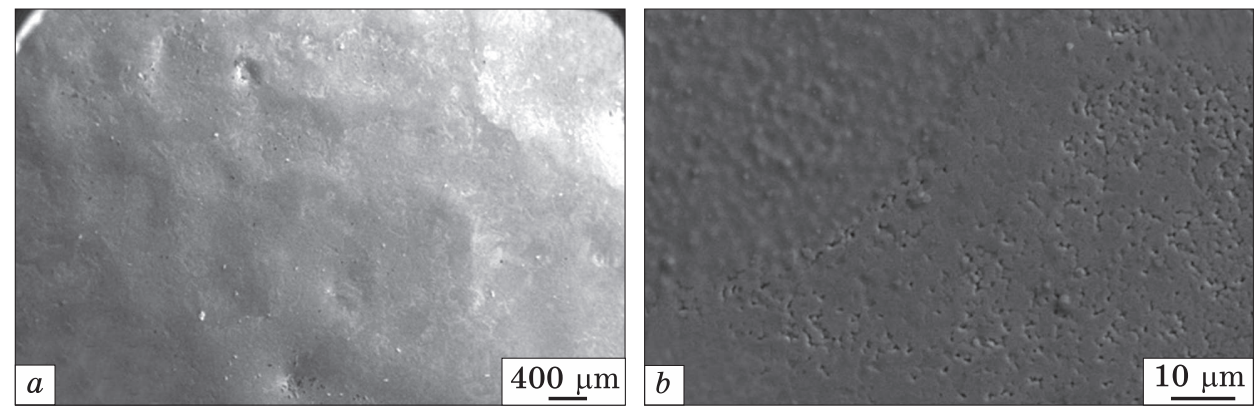

Fig. 4. Scanning electron microscopy (SEM) images for characteristic surface of the electroexplosive coating of $\mathrm{CuO}-\mathrm{Ag}$ after electron beam treatment, where $a-$ general view, and $b$ - structural components. See also Fig. 1 in [D.A. Romanov et al., Mater. Res. Express, 6: 085077 (2019)]; https://doi.org/10.1088/2053-1591/ab220a
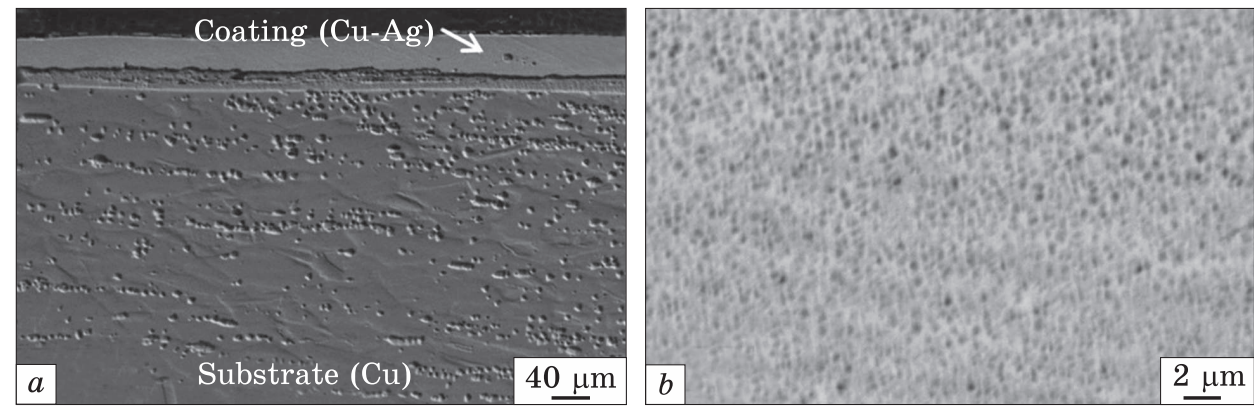

Fig. 5. SEM images for the structure of the electroexplosion coating of the $\mathrm{CuO}-\mathrm{Ag}$ after electron beam processing, where $a$ - general view, $b$ - structural components. See also Fig. 2 in [D.A. Romanov et al., Mater. Res. Express, 6: 085077 (2019)]; https://doi.org/10.1088/2053-1591/ab220a

nents of the molten metal. Under the influence of Brownian forces, the spheres continue a chaotic movement, which stimulates their agglomeration. Self-assembly of particles of the first hierarchical level leads to the formation of a second hierarchical level of globules of size $r_{2}$ from 10 to $15 \mathrm{~nm}$. The formation of this hierarchical level occurs mainly by the cluster-cluster mechanism. Further, such globular particles can be enlarged by sticking to particles in the micrometre range.

An electron beam falling on the treated surface of the electric explosive coating of the $\mathrm{CuO}-\mathrm{Ag}$ system produces ultrafast heating (during the pulse) to the melting temperature of the substrate material. Rapid cooling then occurs due to the removal of heat into the deeper cold layers of the substrate.

The composite electroexplosive coating of the $\mathrm{CuO}-\mathrm{Ag}$ system after treatment with an electron beam consists of components that are a heterogeneous structure consisting of a mixture of more than two phases 


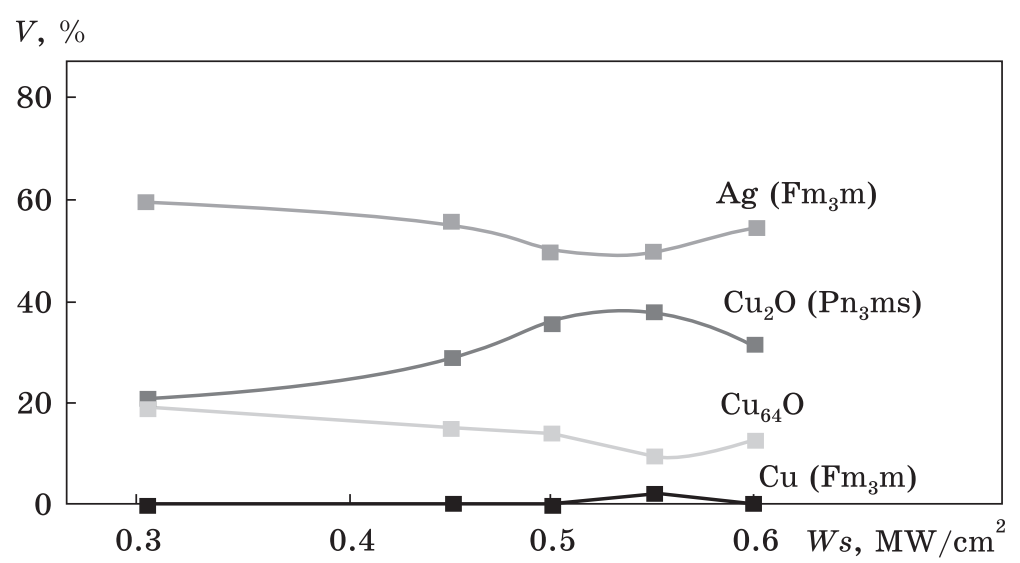

Fig. 6. Dependence of the volume fraction of phases $(V)$ of electroexplosive coatings of $\mathrm{CuO}-\mathrm{Ag}$ on the electron beam power density $\left(W_{s}\right)$. See also Fig. 3 in [D.A. Romanov et al., Mater. Res. Express, 6: 085077 (2019)]; https://doi.org/10.1088/2053-1591/ab220a

(Figs. 4, 5), and one phase (copper oxides) has a significantly higher refractoriness than silver [67]. When one of the phases goes into a liquid state in such a heterogeneous structure, this phase is retained in the pores of the refractory phase by surface tension forces. According to the morphology of the structure and the etching contrast, the formed coating consists of a light silver matrix and dark inclusions of copper oxides with sizes varying from 0.1 to $0.2 \mu \mathrm{m}$ (Fig. $5, b$ ). In contrast to [68], it was found that the electron beam treatment leads to a decrease in the size of copper oxides to values from 1.5 to 5.0 times smaller than those without EBT.

Using the methods of x-ray phase analysis (Fig. 6), we established that the phase composition of the coating of the $\mathrm{CuO}-\mathrm{Ag}$ system after EBT represents the following phases: $\mathrm{Ag}, \mathrm{Cu}_{2} \mathrm{O}, \mathrm{Cu}_{64} \mathrm{O}$ and $\mathrm{Cu}$. The lower copper suboxide $\mathrm{Cu}_{64} \mathrm{O}$ is formed even at room temperature and forms the thinnest film on the surface of an electroexplosive coating. However, with an oxide film thickness $>40 \mathrm{~nm}$, diffusion of oxygen to the copper surface is hindered, and oxidation of the oxide to $\mathrm{CuO}$ occurs. This reaction proceeds quickly at temperatures $T>300{ }^{\circ} \mathrm{C}$. On the other hand, EBT provides the melting of the surface layer of the electroexplosive coating of $\mathrm{Ag}-\mathrm{CuO}$ to the entire coating thickness of $40 \mu \mathrm{m}$, heating it to $>1000{ }^{\circ} \mathrm{C}$. Partial oxidation of the surface layer of the metal also occurs when it melts in air, and the $\mathrm{Cu}_{2} \mathrm{O}$ oxide formed in this process dissolves in the melt. When an electron beam acts on an electric explosion coating of the $\mathrm{CuO}-\mathrm{Ag}$ system, the following chemical reactions proceed in parallel:

$$
\begin{aligned}
& 4 \mathrm{Cu}+\mathrm{O}_{2} \rightarrow 2 \mathrm{Cu}_{2} \mathrm{O} ; 2 \mathrm{Cu}_{2} \mathrm{O}+\mathrm{O}_{2} \rightarrow 4 \mathrm{CuO} ; \\
& 4 \mathrm{CuO} \rightarrow 2 \mathrm{Cu}_{2} \mathrm{O}+\mathrm{O}_{2} ; \mathrm{Cu}+\mathrm{CuO} \rightarrow \mathrm{Cu}_{2} \mathrm{O} .
\end{aligned}
$$



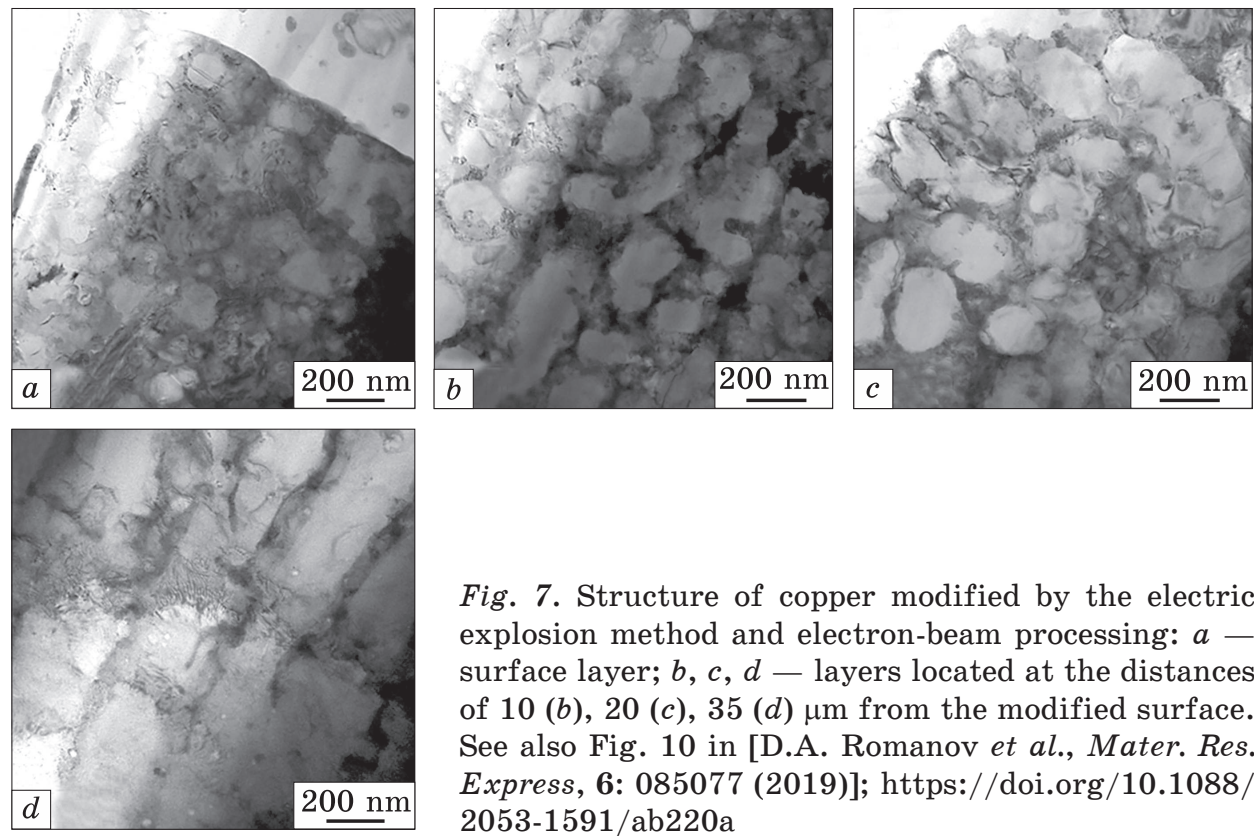

Fig. 7. Structure of copper modified by the electric explosion method and electron-beam processing: $a-$ surface layer; $b, c, d$ - layers located at the distances of $10(b), 20(c), 35(d) \mu \mathrm{m}$ from the modified surface. See also Fig. 10 in [D.A. Romanov et al., Mater. Res. Express, 6: 085077 (2019)]; https://doi.org/10.1088/ 2053-1591/ab220a

Let us analyse the dependence of the volume fraction of the phases of the electroexplosive coating of the $\mathrm{CuO}-\mathrm{Ag}$ system on the power density of the electron beam (Fig. 6). The initial content of the volume fraction of the $\mathrm{Ag}$ phase at $W_{\mathrm{s}}=0.3 \mathrm{MW} / \mathrm{cm}$ is $59.75 \%$ and is maximum for this phase ( $W_{\mathrm{s}}$ is an electron-beam power density). With an increase in power density to $0.5 \mathrm{MW} / \mathrm{cm}^{2}$, the volume fraction of $\mathrm{Ag}$ monotonically decreases to its minimum value of $49.99 \%$. Then, there is an increase in the volume fraction of $\mathrm{Ag}$. The volume fraction of $\mathrm{Ag}$ increases to $55 \%$ at an electron-beam power density of $0.6 \mathrm{MW} / \mathrm{cm}^{2}$.

The phase and elemental composition, the state of the defective substructure of the copper sample modified by the electroexplosive method, were analysed by the transmission electron diffraction microscopy of thin foils. The performed studies show that in the surface layer with a thickness of $\approx 30 \mu \mathrm{m}$, a high-speed cellular crystallization structure is formed, regardless of the distance to the irradiation surface, the characteristic electron-microscopic images of which are shown in Fig. 7, $a-c$. The cell size varies from $150 \mathrm{~nm}$ to $300 \mathrm{~nm}$. Interlayers, the thickness of which varies as $10-70 \mathrm{~nm}$, separate the cells. A dislocation substructure is revealed in the volume of cells in the form of randomly distributed dislocations (Fig. 8, a). Scalar dislocation density $\approx 1 \cdot 10^{10} \mathrm{~cm}^{-2}$. In the transition layer, the structure of dendritic crystallization is revealed. 

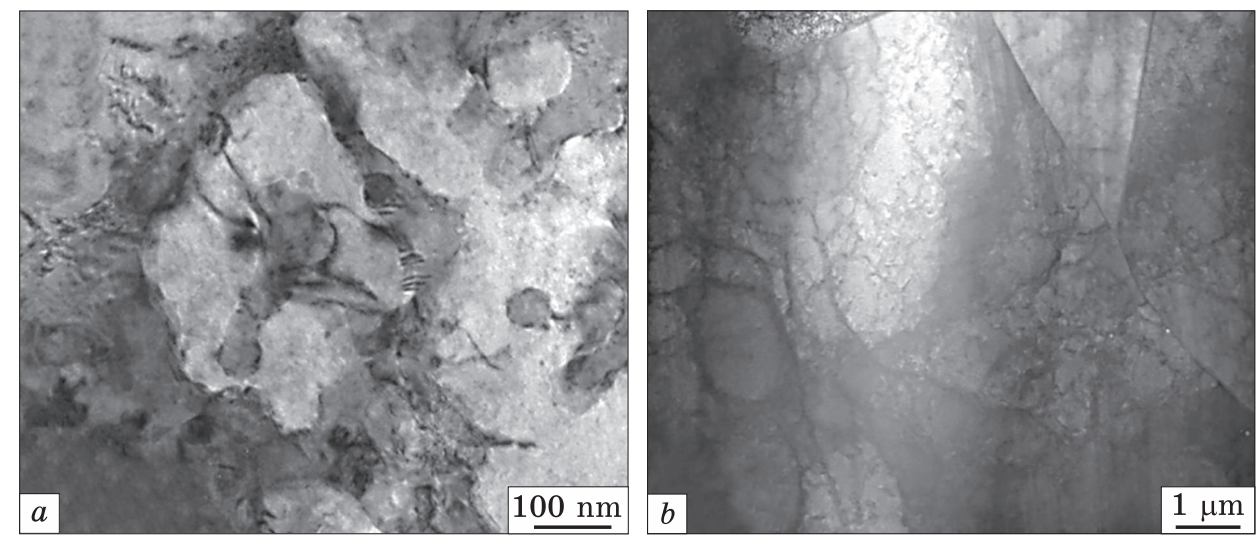

Fig. 8. Structure of copper modified by the electric explosion method and electronbeam processing: $a$ - surface layer; $b, c, d$ - layers located at the distances of 10 (b), $20(c), 35(d) \mu \mathrm{m}$ from the modified surface. See also Fig. 11 in [D.A. Romanov et al., Mater. Res. Express, 6: 085077 (2019)]; https://doi.org/10.1088/2053-1591/ ab220a
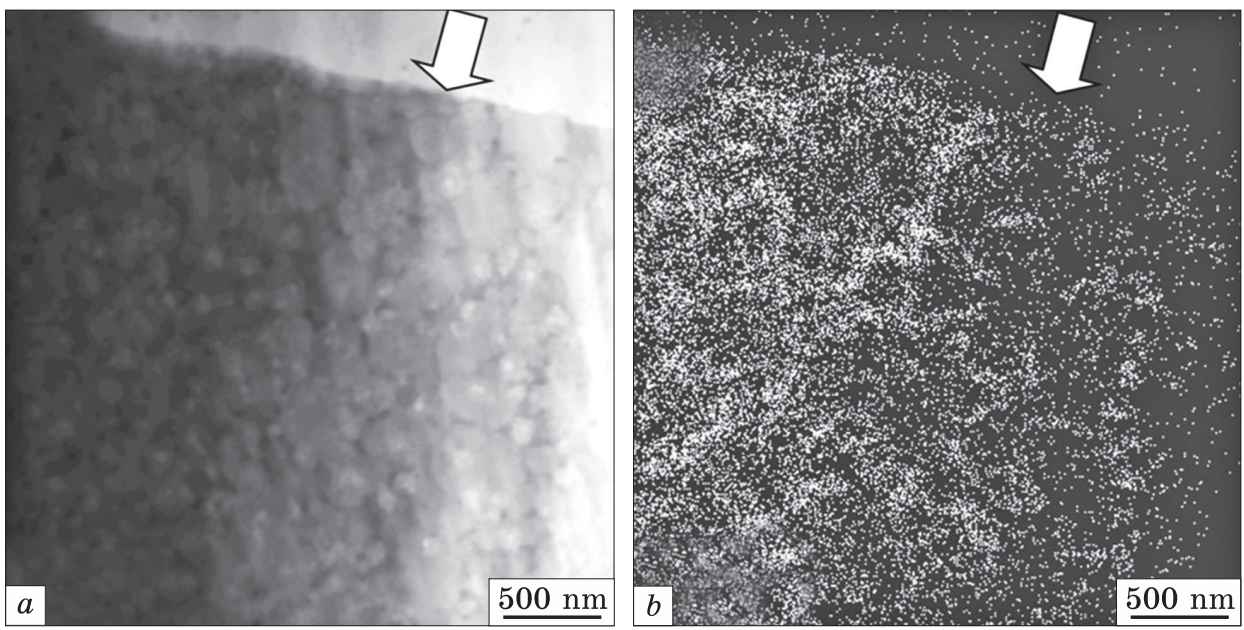

Fig. 9. Electron microscopic images of the structure of the surface layer of copper subjected to EES and EBT: $a$ - STEM-image; $b$ - image of the structure obtained in the characteristic x-ray emission of Ag atoms. See also Fig. 12 in [D.A. Romanov et al., Mater. Res. Express, 6: 085077 (2019)]; https://doi.org/10.1088/2053-1591/ ab220a

At a distance of more than $40 \mu \mathrm{m}$ from the surface of the modification, a thermal influence layer is revealed that has a polycrystalline structure and is a solid solution based on copper.

In the volume of copper grains, a cellular-net dislocation substructure is observed, a characteristic image of which is shown in Fig. 8, $b$. 

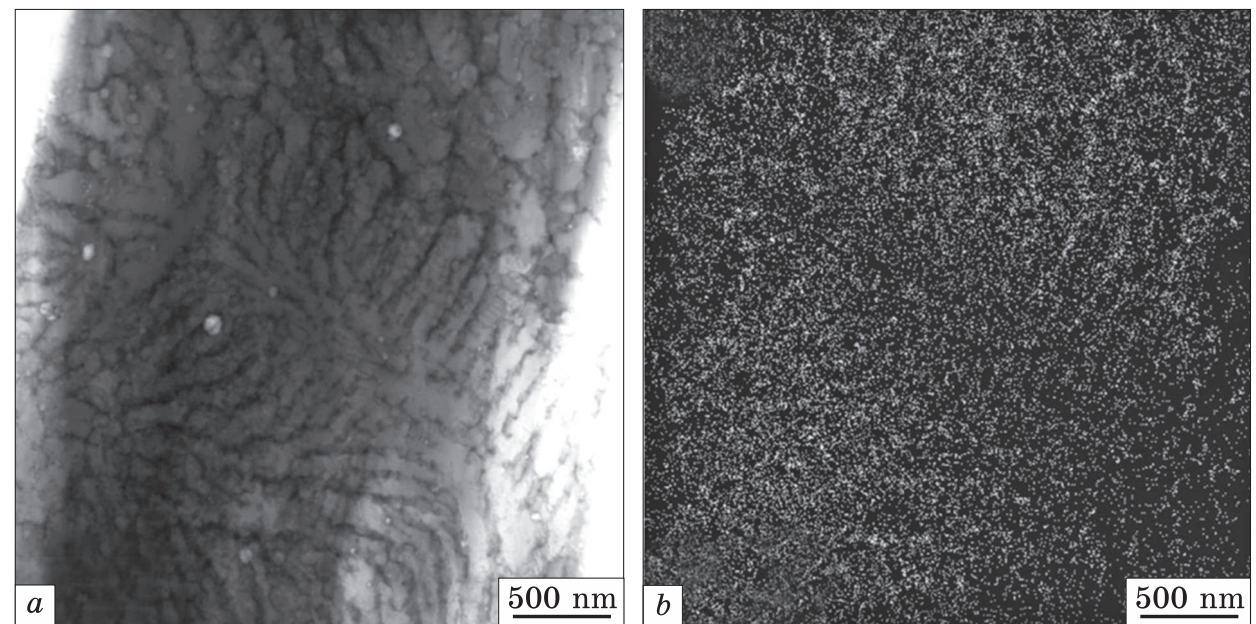

Fig. 10. Electron microscopic images of the surface layer structure of copper subjected to EES and EBT. The analysed layer is located at a depth of $\approx 30 \mu \mathrm{m}$. Here, $a-$ conventional transmission electron microscopy (CTEM) image; $b$ - image of the structure (a), obtained in the characteristic x-ray emission of $\mathrm{Ag}$ atoms. See also Fig. 13 in [D.A. Romanov et al., Mater. Res. Express, 6: 085077 (2019)]; https:// doi.org/10.1088/2053-1591/ab220a

The cell size varies in the range $350-700 \mathrm{~nm}$. The scalar dislocation density is $0.9 \cdot 10^{10} \mathrm{~cm}^{-2}$.

The distribution of silver atoms in the modified copper layer was studied by x-ray microanalysis of thin foils. The research results are shown in Figs. 9 and 10. Analysing the results presented in Fig. 6, it can be concluded that in the structure of high-speed cellular crystallization formed in the surface layer, $\mathrm{Cu}$ atoms form the cell volume, while $\mathrm{Ag}$ atoms are located mainly along the cell boundaries, forming extended interlayers (Fig. 9, $b$ ).

In the structure of dendroid crystallization, $\mathrm{Ag}$ atoms are located mainly along the borders of dendrites, forming discontinuous lines of separately located particles (Fig. 10, b). Particle sizes vary from $20 \mathrm{~nm}$ to $30 \mathrm{~nm}$. In the volume of copper grains forming the heat-affected zone, Ag atoms were not detected by x-ray spectral analysis.

Studies of electroexplosive coatings of the $\mathrm{CuO}-\mathrm{Ag}$ system after EBT are confirmed by the results of x-ray diffraction analysis (Fig. 11).

Obtained results suggest that the formation of a multielement multiphase submicron-nanoscale state in the surface layer will lead to an increase in the strength (nanoscale hardness) and tribological (wear resistance) properties of copper subjected to EES. 

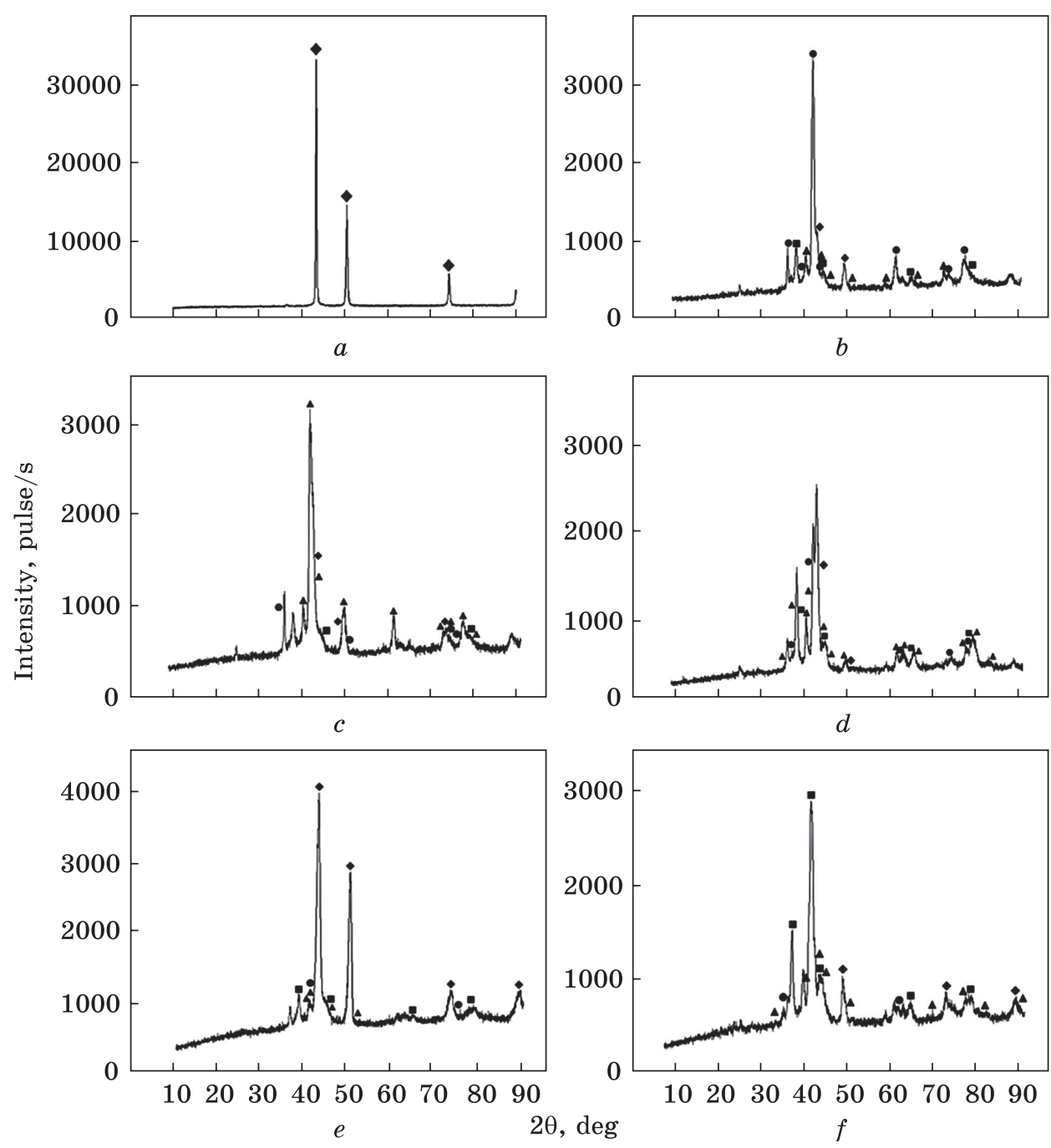

Fig. 11. Areas of radiographs of copper without coating (a) and after electrical explosion spraying of coating system $\mathrm{CuO}-\mathrm{Ag}$ and electron beam processing in different (1-5) modes. The symbols indicate the phases $\mathrm{Cu}(\bullet), \mathrm{Ag}(\boldsymbol{\bullet}), \mathrm{Cu}_{64} \mathrm{O}(\boldsymbol{\Delta})$, and $\mathrm{Cu}_{2} \mathrm{O}(\bullet)$

\subsection{Structure of Electroerosion-Resistant Coatings of $\mathrm{ZnO}-\mathrm{Ag}$}

The defective substructure of the electroexplosive coating of the $\mathrm{ZnO}$ Ag system was studied by analysing transverse etched sections (Fig. 12). It is established that the EES of copper is accompanied by the formation of a multilayer structure. The thickness of the surface layer (Fig. 12, $a$, layer 1) having a submicrocrystalline (150-230 $\mathrm{nm})$ structure 

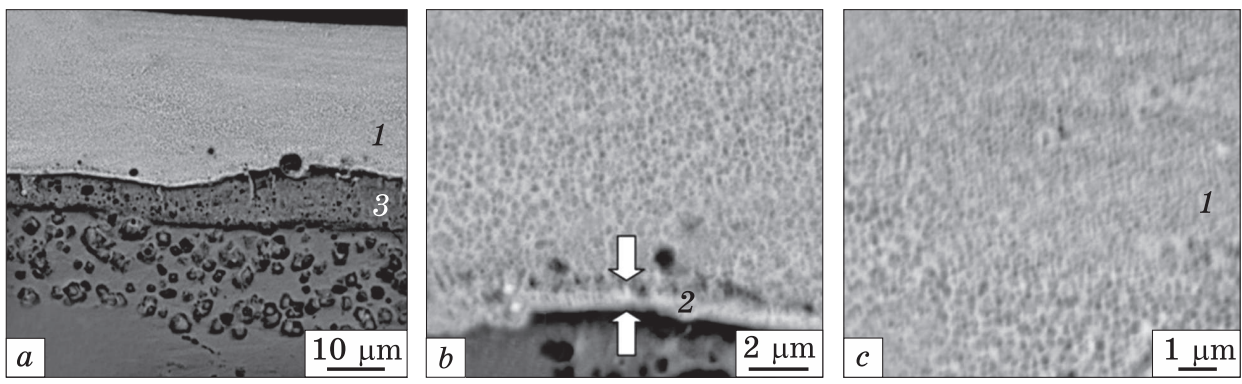

Fig. 12. The structure of the transverse section of $\mathrm{Cu}$ sample subjected to EES: $a-$ general view of the coating; $b$ - structure formed at the boundary of the coating with a substrate; $c$ - electron microscopic image of the surface layer structure; 1 - surface layer; 2 - transition layer; 3 - thermal influence layer. See Fig. 3 in [D. Romanov et al., J. Mater. Res. Technol., 8, No. 6: 5515 (2019)]; https://doi. org $/ 10.1016 /$ j.jmrt.2019.09.019
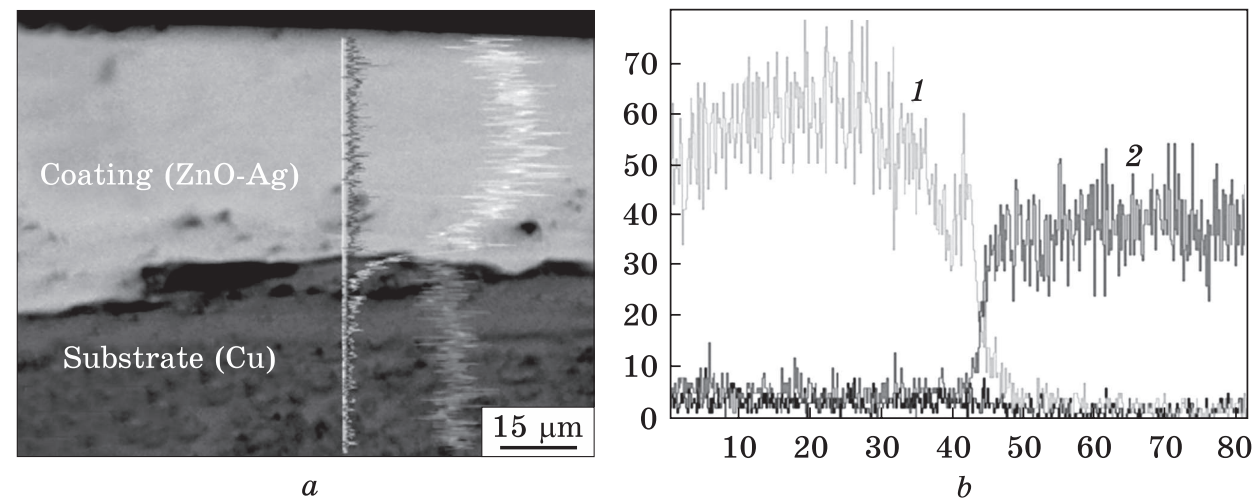

Fig. 13. The $\mathrm{Ag}$ and $\mathrm{Cu}$ distribution in the copper electrical contact subjected to the EES coating of $\mathrm{ZnO}-\mathrm{Ag}: a-$ general view of the coating with the imposition of profiles; $b$ - concentration profiles of $\mathrm{Ag}$ (curve 1) and $\mathrm{Cu}$ (curve 2) atoms. See also Fig. 4 in [D. Romanov et al., J. Mater. Res. Technol., 8, No. 6: 5515 (2019)]; https:// doi.org/10.1016/j.jmrt.2019.09.019

(Fig. 12, c) varies over a wide range and varies as 30-60 $\mu \mathrm{m}$. The surface layer is separated from the thermal influence layer by a transition layer with a thickness of (1.0-1.3) $\mu \mathrm{m}$ (Fig. 12, b, layer 2). It should be noted that the transition layer contains a large number of micropores (Fig. 12, $a, b$ ).

X-ray spectral analysis methods have been used to study the elemental composition of the modified layer of copper electrical contact. The research results presented in Fig. 13 indicate that silver is the main element of the surface layer. In the transition layer, the concentration of silver atoms decreases rapidly and in the main volume of the copper electrical contact, silver atoms are detected in a minimal amount. 

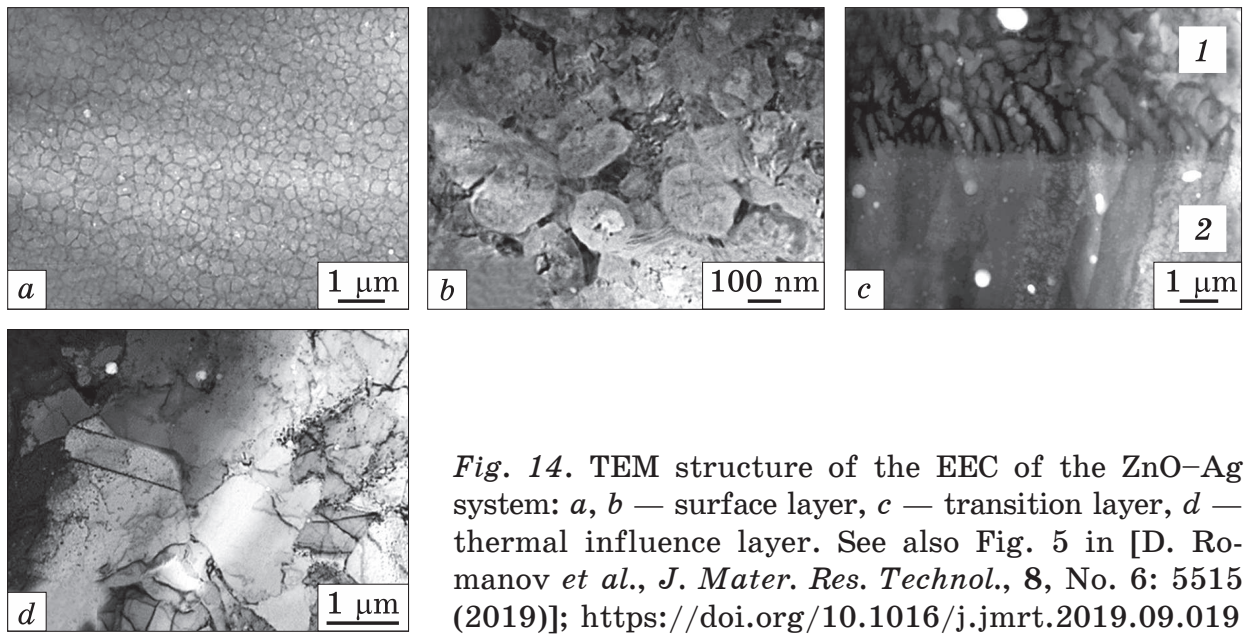

Fig. 14. TEM structure of the EEC of the $\mathrm{ZnO}-\mathrm{Ag}$ system: $a, b-$ surface layer, $c-$ transition layer, $d-$ thermal influence layer. See also Fig. 5 in [D. Romanov et al., J. Mater. Res. Technol., 8, No. 6: 5515 (2019)]; https://doi.org/10.1016/j.jmrt.2019.09.019
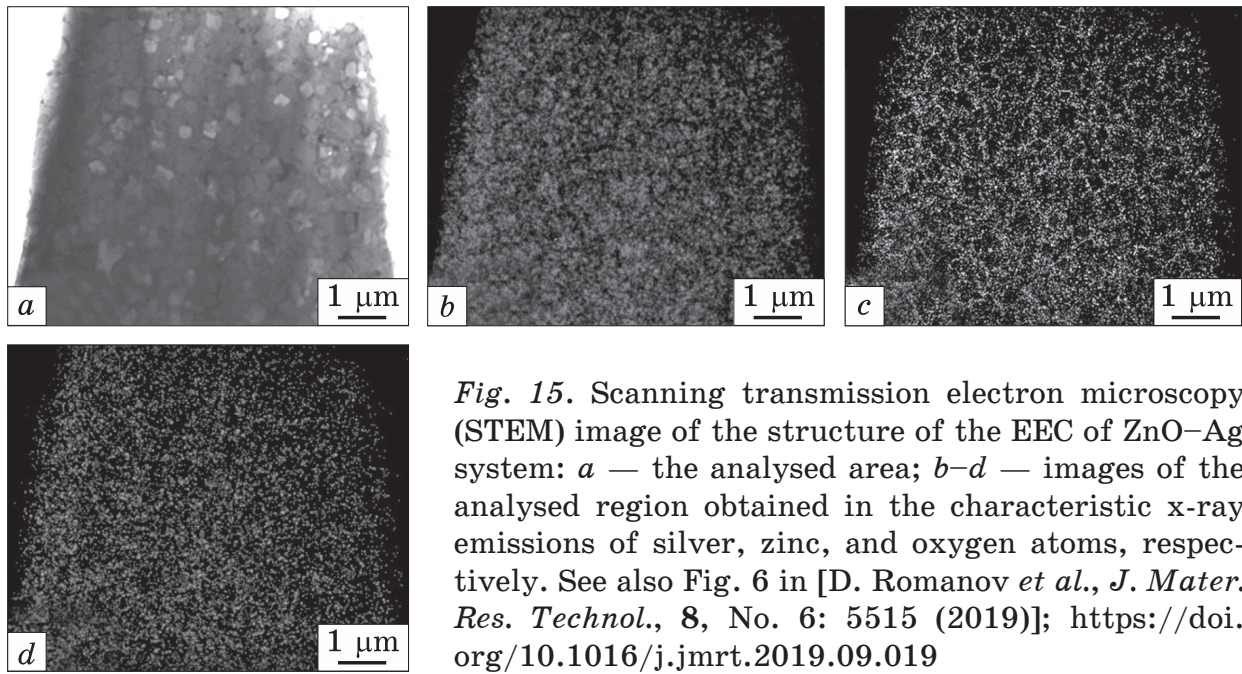

Fig. 15. Scanning transmission electron microscopy (STEM) image of the structure of the EEC of $\mathrm{ZnO}-\mathrm{Ag}$ system: $a-$ the analysed area; $b-d-$ images of the analysed region obtained in the characteristic $\mathrm{x}$-ray emissions of silver, zinc, and oxygen atoms, respectively. See also Fig. 6 in [D. Romanov et al., J. Mater. Res. Technol., 8, No. 6: 5515 (2019)]; https://doi. $\operatorname{org} / 10.1016 /$ j.jmrt.2019.09.019

The phase and elemental composition, the state of the defective substructure of the copper electrical contact subjected of the coating of the $\mathrm{ZnO}-\mathrm{Ag}$ system subjected to EES, were analysed by transmission electron diffraction microscopy of thin foils. The performed studies show that in the surface layer with a thickness of up to $60 \mu \mathrm{m}$, a structure of high-speed cellular crystallization is formed, regardless of the distance to the irradiation surface and its characteristic electron microscopic images are shown in Fig. 14, $a, b$. The cells have a rounded shape (Fig. 14, a). The cell size ranges from $150 \mathrm{~nm}$ to $400 \mathrm{~nm}$. The cells are separated by interlayers (Fig. 14, b), the thickness of which varies from $15 \mathrm{~nm}$ to $50 \mathrm{~nm}$. A dislocation substructure in the form of randomly distributed 

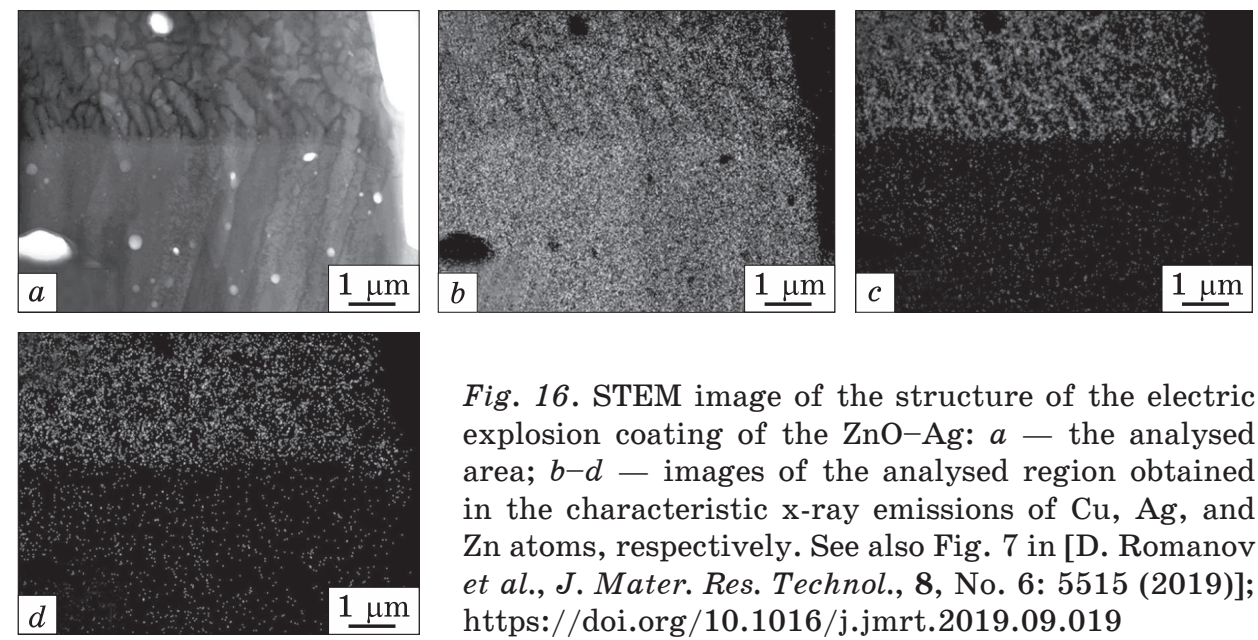

Fig. 16. STEM image of the structure of the electric explosion coating of the $\mathrm{ZnO}-\mathrm{Ag}: a-$ the analysed area; $b-d$ - images of the analysed region obtained in the characteristic $\mathrm{x}$-ray emissions of $\mathrm{Cu}, \mathrm{Ag}$, and Zn atoms, respectively. See also Fig. 7 in [D. Romanov et al., J. Mater. Res. Technol., 8, No. 6: 5515 (2019)]; https://doi.org/10.1016/j.jmrt.2019.09.019
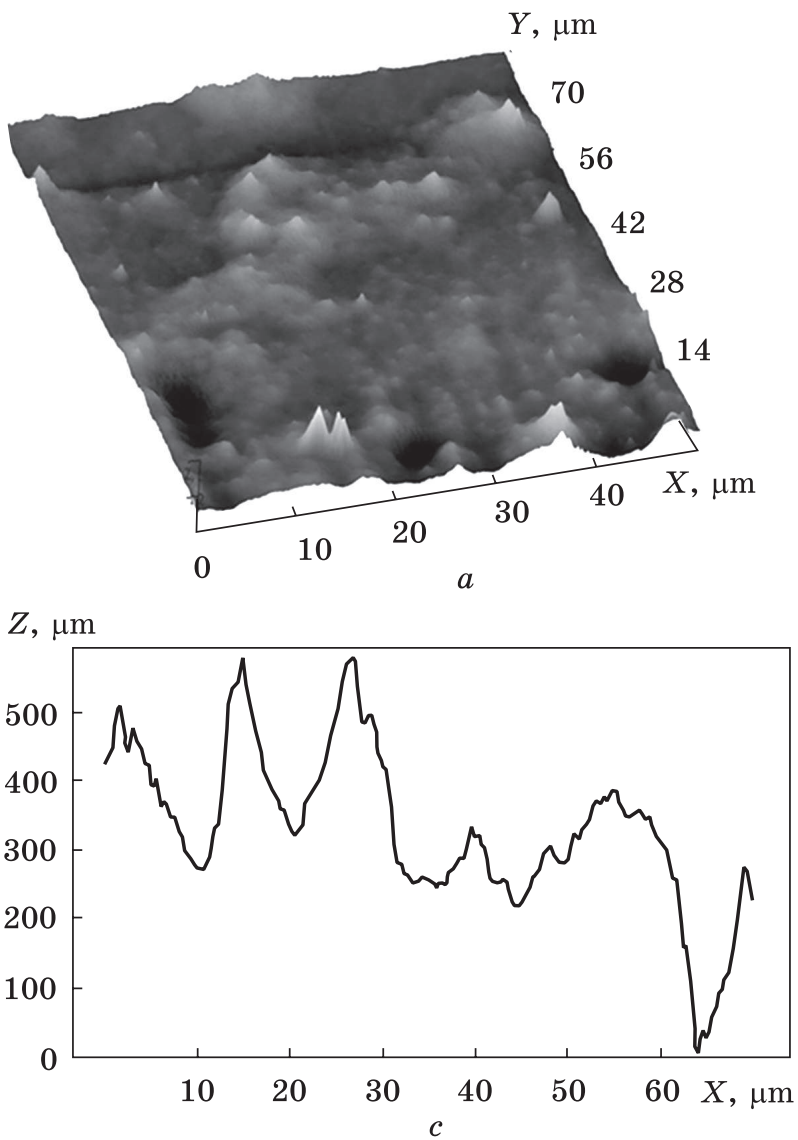

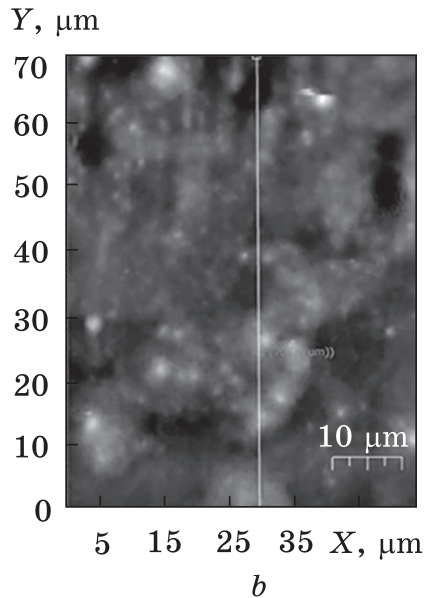

Fig. 17. The coating structure of the $\mathrm{ZnO}-\mathrm{Ag}$ identified by atomic force microscopy: $a$ - distribution of the relief unevenness (perspective view); $b-$ the position of the secant (top view); $c-$ distribution of roughness along the base length. See also Fig. 8 in [D. Romanov et al., J. Mater. Res. Technol., 8, No. 6: 5515 (2019)]; https://doi. org/10.1016/j.jmrt.2019. 09.019 
dislocations is revealed in the volume of the cells (Fig. 14, b). Scalar dislocation density $\approx 2.1 \cdot 10^{10} \mathrm{~cm}^{-2}$. The transition layer has a dendritic crystallization structure from the side of the electroexplosive deposition layer (Fig. 14, $c$, layer 1) and a plate type structure from the side of the thermal influence layer (Fig. 14, $c$, layer 2). The layer of thermal influence of the copper electrical contact has a grain-subgrain structure (Fig. 14, d). A dislocation substructure in the form of randomly distributed dislocations is observed in the volume of copper grains (Fig. $14 \mathrm{~d}$ ). The scalar dislocation density is $\approx 1.3 \cdot 10^{10} \mathrm{~cm}^{-2}$. It should be noted that the electron microscopic image of the structure of the thermal influence layer contains a large number of bending extinction contours [69] (Fig. 14, $d$ ), which indicates a high level of torsion curvature of the material due to internal stress fields [70].

The distribution of silver, zinc, and oxygen atoms in an electric explosion coating was studied by x-ray microanalysis of thin foils. The research results are shown in Figs. 15 and 16. Analysing the results presented in Fig. 15, we can conclude that in the structure of highspeed cellular crystallization formed in the surface layer, the cell volume is formed mainly by $\mathrm{Ag}$ atoms (Fig. 15, b), Zn atoms (Fig. 15, c) and oxygen atoms (Fig. 15, $d$ ) which are located mainly along the boundaries of the cells, forming extended interlayers.

Table 2. Relative content of chemical elements in surface layer of electroexplosive coating (EEC) of $\mathrm{ZnO}-\mathrm{Ag}$ (fit factor is 0.1921) *

\begin{tabular}{|l|c|r|r|c|r|}
\hline \multicolumn{1}{|c|}{ Element } & $E, \mathrm{keV}$ & mass.\% & \multicolumn{1}{c|}{ Amount } & Error, \% & \multicolumn{1}{c|}{ at.\% } \\
\hline Ag (L) & 2.984 & 51.83 & 101179.97 & 0.01 & 63.89 \\
$\mathrm{Zn}(\mathrm{K})$ & 8.630 & 31.43 & 33371.70 & 0.01 & 22.82 \\
O (K) & 0.525 & 16.74 & 18340.04 & 0.26 & 13.29 \\
Total & - & 100.00 & - & - & 100.00 \\
\hline
\end{tabular}

* See also Table 1 in [D. Romanov et al., J. Mater. Res. Technol., 8, No. 6: 5515 (2019)]; https://doi.org/10.1016/j.jmrt.2019.09.019

Table 3. Relative content of chemical elements in transition layer of $\mathrm{Cu}$ modified via electrical explosion method*

\begin{tabular}{|l|c|c|c|c|c|}
\hline \multicolumn{1}{|c|}{ Element } & $E, \mathrm{keV}$ & Mass. $\%$ & Amount & Error, $\%$ & At.\% \\
\hline $\mathrm{Cu}(\mathrm{K})$ & 8.040 & 86.84 & 179363 & 0.00 & 91.4 \\
$\mathrm{Ag}(\mathrm{L})$ & 2.984 & 8.6 & 9663.6 & 0.01 & 5.33 \\
$\mathrm{Zn}(\mathrm{K})$ & 3.443 & 4.28 & 4812.1 & 0.01 & 2.41 \\
O (K) & 0.525 & 0.28 & 595 & 0.61 & 0.86 \\
Total & - & 100 & - & - & 100 \\
\hline
\end{tabular}

* See also Table 2 in [D. Romanov et al., J. Mater. Res. Technol., 8, No. 6: 5515 (2019)]; https://doi.org/10.1016/j.jmrt.2019.09.019 

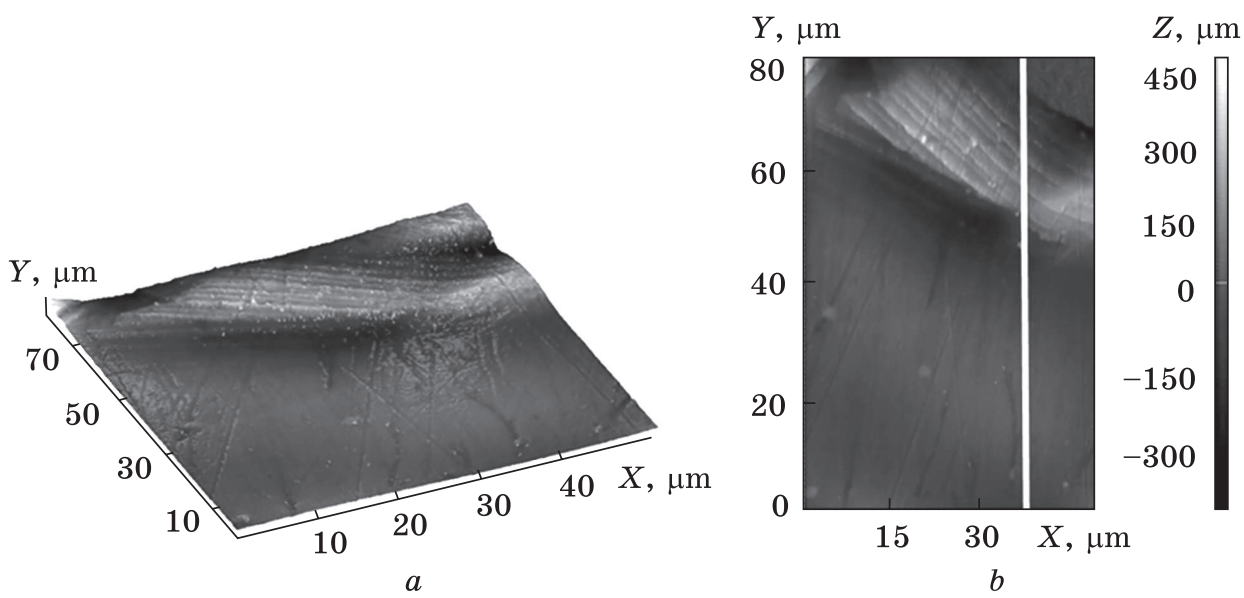

$Z, \mu \mathrm{m}$

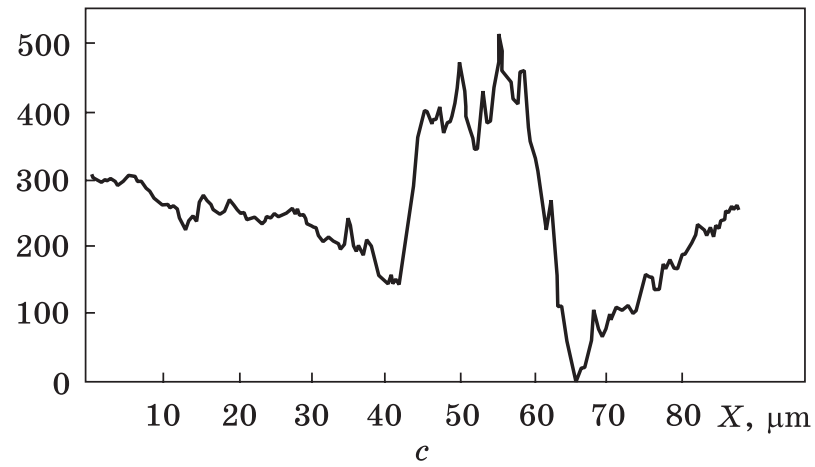

Fig. 18. Structure at the boundary of the $\mathrm{ZnO}-\mathrm{Ag}$ coating with a $\mathrm{Cu}$ substrate identified by atomic force microscopy: $a-$ distribution of the relief unevenness (perspective view); $b$ - the position of the secant (top view); $c-$ dis-

tributionof roughness along the base length. See also Fig. 9 in [D. Romanov et al., J. Mater. Res. Technol., 8, No. 6: 5515 (2019)]; https://doi.org/10.1016/j.jmrt. 2019.09.019

The relative content of atoms forming the surface layer of the sprayed electroexplosive coating is given in Table 2. Analysing the results in Table 2, one can note that the main elements of the surface layer are silver, zinc, and oxygen, which is to be expected.

In the structure of the transition layer (layer with dendroid crystallization), silver and zinc atoms are located mainly along the boundaries of dendrites (Fig. 16, $c, d$ ). In the volume of copper grains that form the heat-affected zone, silver and zinc atoms are detected in small quantities by $\mathrm{x}$-ray spectral analysis methods.

The relative content of atoms forming the transition layer of the electroexplosive coating of the $\mathrm{ZnO}-\mathrm{Ag}$ system is shown in Table 3 . It can be noted that the concentration of silver and zinc atoms in the transition layer is significantly lower than in the surface layer, which is in a good agreement with the results of x-ray spectral analysis obtained by scanning electron microscopy (Fig. 13). 


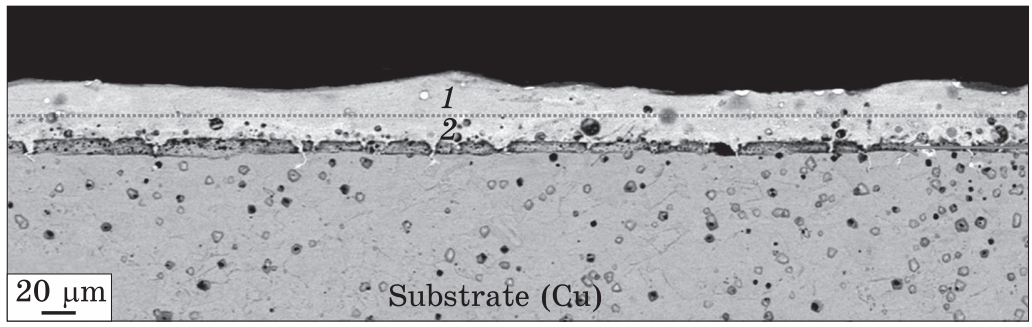

Fig. 19. SEM image of the structure of the EEC of the ZnO-Ag after the EBT: 1 - surface layer obtained by two-stage processing of EES + EBT; 2 - layer of EEC unaffected by EBT; dashed line - boundary between layers 1, 2; arrow boundary of the electroexplosive coating with $\mathrm{Cu}$ substrate. See also Fig. 1 in [D.A. Romanov et al., AIP Conf. Proc., 2167, No. 1: 020295]; https://doi.org/ $10.1063 / 1.5132162$
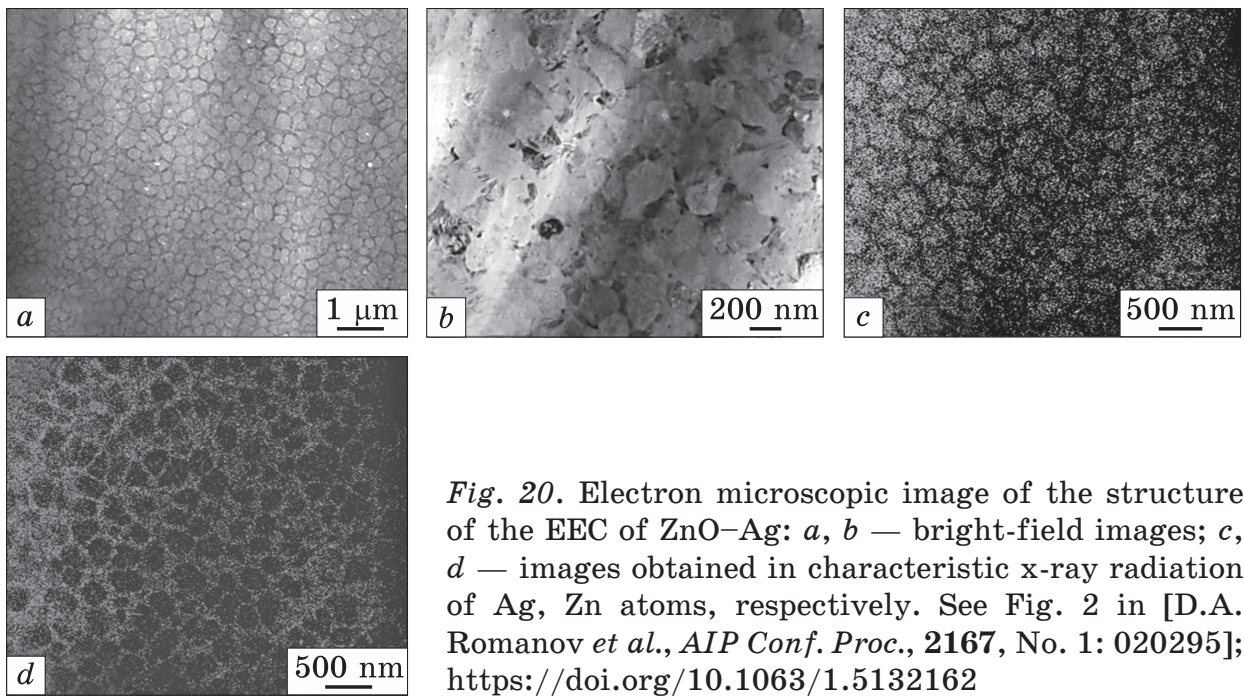

Fig. 20. Electron microscopic image of the structure of the EEC of $\mathrm{ZnO}-\mathrm{Ag}: a, b-$ bright-field images; $c$, $d$ - images obtained in characteristic x-ray radiation of $\mathrm{Ag}, \mathrm{Zn}$ atoms, respectively. See Fig. 2 in [D.A. Romanov et al., AIP Conf. Proc., 2167, No. 1: 020295]; https://doi.org/10.1063/1.5132162

By atomic force microscopy, individual $\mathrm{ZnO}$ particles of various shapes with a size of 10-15 $\mathrm{nm}$ were randomly located in a silver matrix (Fig. 17, a). Spherical $\mathrm{Zn}$ particles $2-5 \mathrm{~nm}$ in size were also found. The fractions of the silver matrix, large and small particles of $\mathrm{ZnO}$ in the coating are estimated at 60,15 , and $25 \%$. The unevenness of the coating profile was $550.6 \mathrm{~nm}$, and the cavities were $300.5 \mathrm{~nm}$ deep. At the coating/substrate interface on the coating side, there are surface periodic structures with an average period of $3 \mathrm{~nm}$ (Fig. 18).

As a result of the combined treatment, including the EES of the $\mathrm{ZnO}-\mathrm{Ag}$ system coating and its subsequent EBT, a coating is formed in which four layers are distinguished, which differ in the state of the structure. These are the following layers: the surface layer obtained by 

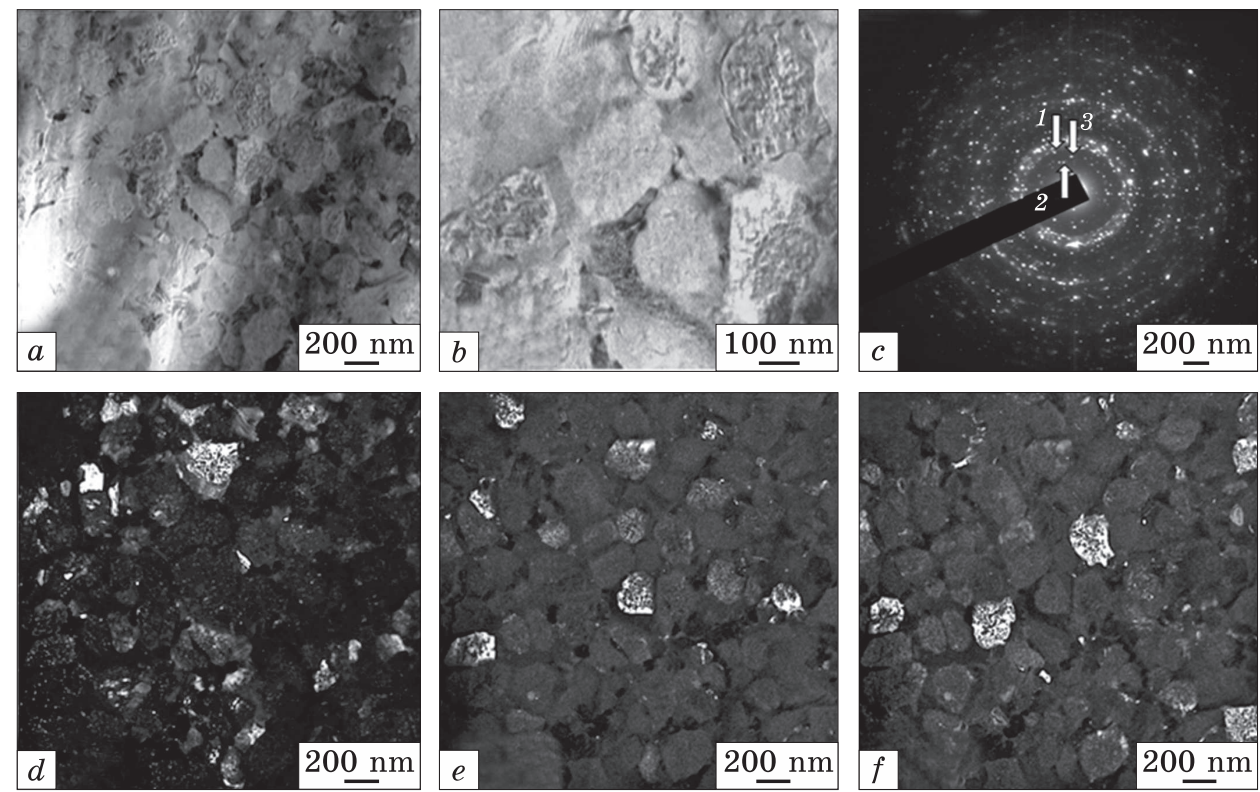

Fig. 21. Electron microscopic image of the structure of the cellular crystallization of the EEC of $\mathrm{ZnO}-\mathrm{Ag}: a, b$ - bright-field images; $c$ - microelectron diffraction pattern; $d-f$ - dark-field images obtained in the reflections of [111] $\mathrm{Ag}(d)$, [110] $\mathrm{ZnO}(e),\left[\begin{array}{lll}0 & 16 & 2\end{array}\right] \mathrm{Ag}_{5} \mathrm{Zn}_{8}(f)$; arrows $(c)$ indicate reflexes in which dark-field images $1(d), 2(e), 3(f)$ were obtained. See Fig. 3 in [D.A. Romanov et al., AIP Conf. Proc., 2167, No. 1: 020295]; https://doi.org/10.1063/1.5132162

two-stage processing of EES + EBT (layer 1 in Fig. 19); the boundary between the surface layer of EES + EBT and the layer of EES not affected by EBT (indicated by a dashed line in Fig. 19); a layer of electroexplosive coating not affected by EBT (layer 2 in Fig. 19) and the boundary of the electroexplosive coating with a copper substrate (indicated by the arrow in Fig. 19).

Let us consider the structure of each of the layers of the electroexplosive coating of the $\mathrm{ZnO}-\mathrm{Ag}$ system after EBT.

The surface layer obtained by two-stage processing of EES + EBT (layer 1 in Fig. 19). Studies performed by transmission electron diffraction microscopy of thin foils showed that the surface layer obtained by two-stage processing of the EES + EBT of the $\mathrm{ZnO}-\mathrm{Ag}$ system at a distance of $\approx 15 \mu \mathrm{m}$ from the surface has the structure of high-speed cellular crystallization (Fig. 20 a). The cells have a rounded shape. The cell size varies from $170 \mathrm{~nm}$ to $300 \mathrm{~nm}$. The cells are separated by interlayers of the second phase (Fig. 20,b). The transverse dimensions of the interlayers vary from $35 \mathrm{~nm}$ to $73 \mathrm{~nm}$. Using x-ray microspectral analysis, it was found that the volume of the cells is enriched with silver atoms (Fig. 20, c); the layers are enriched with zinc atoms 


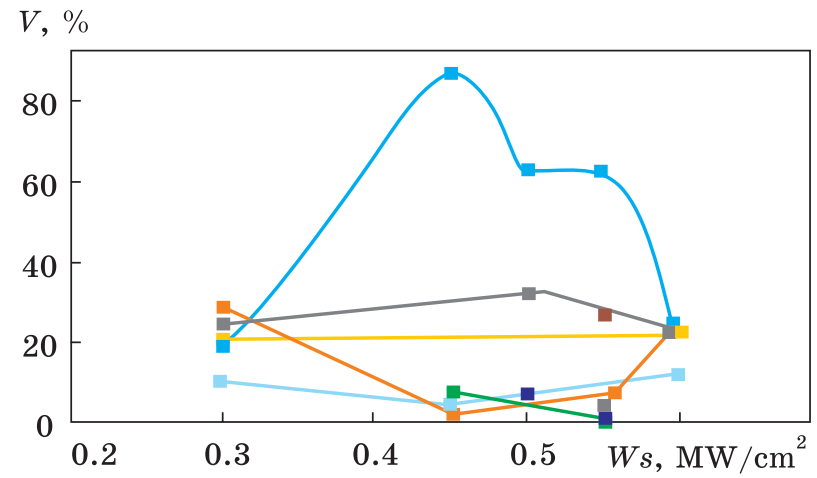

Fig. 22. Dependence of the volume fraction of phases $(V)$ of the electroexplosive coating of the $\mathrm{ZnO}-\mathrm{Ag}$ on the electron beam power density $\left(W_{s}\right)$. Here, « - Ag; $-\mathrm{Cu}$; $\mathrm{CuZn} ;-\mathrm{ZnO} ;-\mathrm{Ag}_{5} \mathrm{Zn}_{8}$ - $-\mathrm{Cu}_{2} \mathrm{O} ;-\mathrm{Ag}_{2} \mathrm{O} ; \mathbf{-}-$ $\mathrm{Cu}_{0.67} \mathrm{Zn}_{0.33} ;$ - - AgZn. See also Fig. 4 in [D.A. Romanov et al., AIP Conf. Proc., 2167, No. 1: 020295]; https://doi. org $/ 10.1063 / 1.5132162$
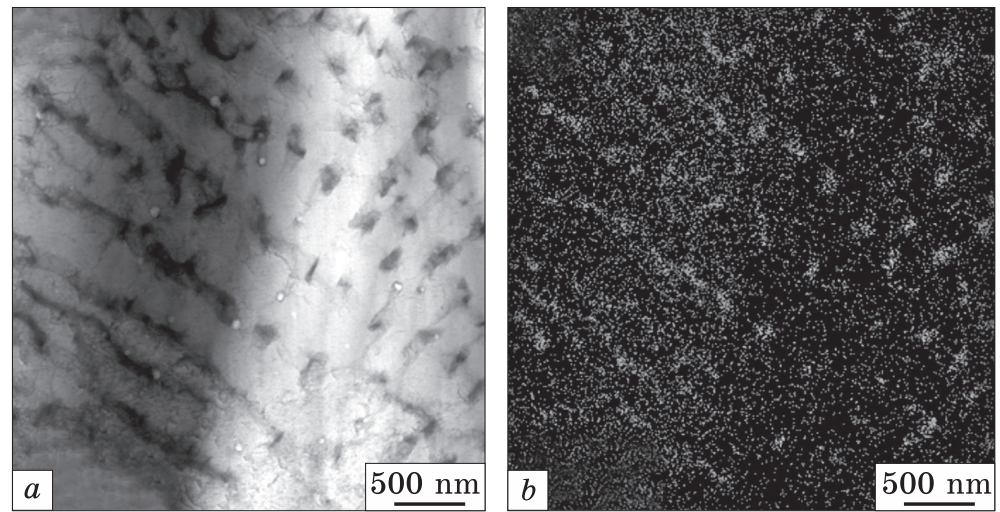

Fig. 23. Electron microscopic image of the structure at the interface between the surface layer of EES + EBT and the layer of EES not affected by EBT: $a$ - bright field image; $b$ - image obtained in the characteristic $\mathrm{x}$-ray radiation of $\mathrm{Ag}$ atoms

(Fig. 20,d). The relative silver (zinc) atom content of the foil portion is $55.1(30.6)$ at. $\%$.

Figure 21 shows the results of a phase analysis of the structure of cellular crystallization of an electroexplosive coating. Analysis of the microelectron diffraction pattern (Fig. 21,c) obtained from the foil plot, the image of which is shown in (Fig. 25,a), allowed to reveal reflections of silver, zinc, zinc compounds with oxygen. Reflexes of the detected phases are located on the microelectron diffraction pattern (Fig. 21, c) close to each other, which does not allow us to identify confidently the phase arrangement in dark-field images. It can only be noted, based on the results of x-ray microspectral analysis (Fig. 20), that the crystallization cells formed by the silver-based solid solution contain nanosize $(\approx 20 \mathrm{~nm})$ particles of the second phases. The cells are separated by extended interlayers, which also have a nanostructured structure and are formed by phases based on zinc and oxygen (Fig. 20, b). 

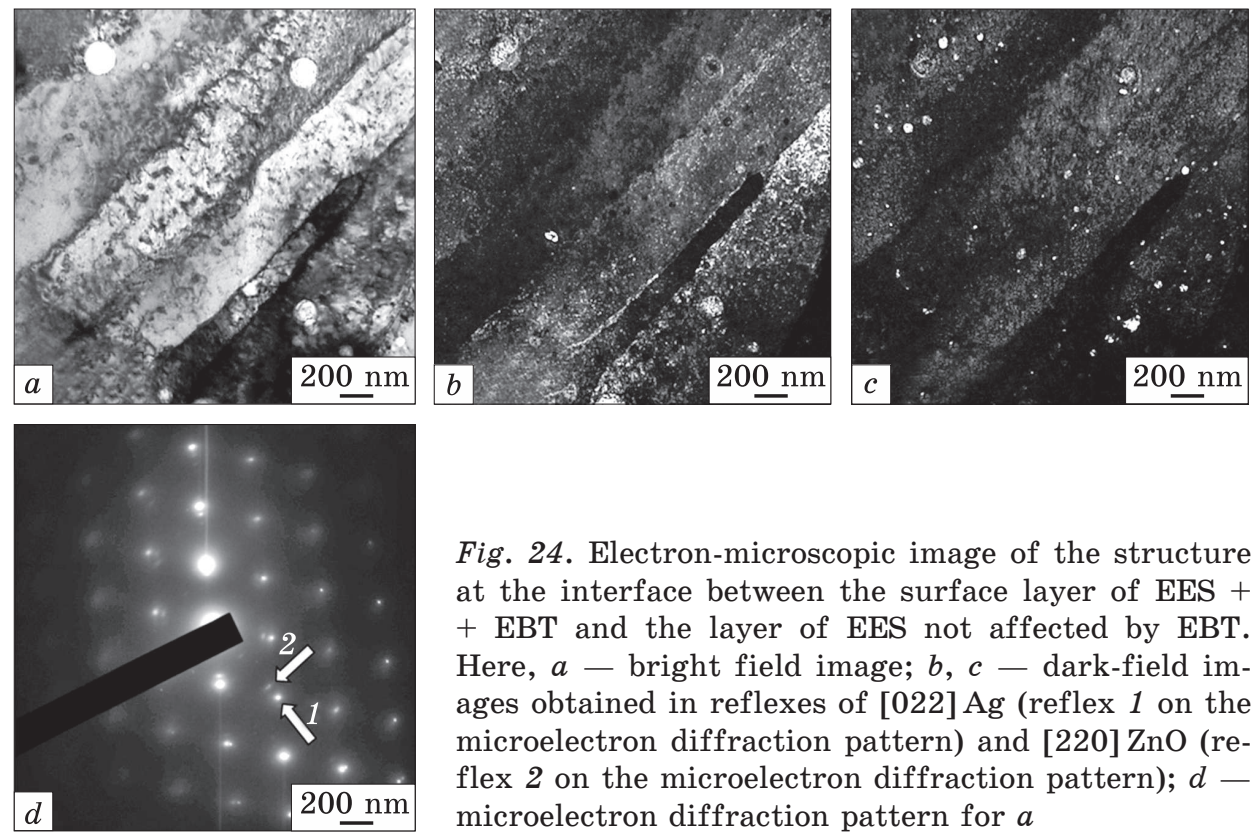

Fig. 24. Electron-microscopic image of the structure at the interface between the surface layer of EES + + EBT and the layer of EES not affected by EBT. Here, $a$ - bright field image; $b, c$ - dark-field images obtained in reflexes of [022] Ag (reflex 1 on the microelectron diffraction pattern) and [220] $\mathrm{ZnO}$ (reflex 2 on the microelectron diffraction pattern); $d-$ microelectron diffraction pattern for $a$

The method of x-ray diffraction analysis was used to study the crystal lattice parameters and the values of coherent scattering (CSR) regions of phases formed in the surface layer obtained by two-stage processing EES + EBT (layer 1 in Fig. 19). Let us analyse the dependence of the volume fraction of the phases of the electric explosive coating of the $\mathrm{ZnO}-\mathrm{Ag}$ system on the power density of the electron beam (Fig. 22). The phase composition of this layer consists of the following phases: $\mathrm{Ag}$, $\mathrm{ZnO}, \mathrm{Cu}, \mathrm{CuZn}, \mathrm{Ag}_{5} \mathrm{Zn}_{8}, \mathrm{Cu}_{2} \mathrm{O}, \mathrm{Ag}_{2} \mathrm{O}, \mathrm{Cu}_{0.67} \mathrm{Zn}_{0.33}$, and $\mathrm{AgZn}$.

The initial value of the volume fraction of $\mathrm{Ag}$ (Fig. 22, $\mathrm{n}$ is the blue marker) is $19.16 \%$ and is the smallest at $0.3 \mathrm{MW} / \mathrm{cm}^{2}$. With an increase in power density, the volume fraction increases to a maximum value of $85.97 \%$ at $0.45 \mathrm{MW} / \mathrm{cm}^{2}$. After, the volume fraction of $\mathrm{Ag}$ decreases to a final value of $21.98 \%$ at $0.6 \mathrm{MW} / \mathrm{cm}^{2}$.

The boundary between the surface layer of EES + EBT and the layer of EES not affected by EBT (indicated by a dashed line in Fig. 19). The region of the material located at the interface between the surface layer of EES + EBT and the EES layer not affected by EBT has a lamellar structure formed by silver plates separated by zinc interlayers. This is evidenced by the results of x-ray microspectral analysis, presented in Fig. 23. The silver concentration of this portion of the foil is $90.5 \mathrm{wt} \%$ (92.9 at.\%); zinc - 5.4 wt.\% (3.3 at.\%).

The results obtained by $\mathrm{x}$-ray spectral analysis were confirmed by microdiffraction electron microscopic examination of the structure of 

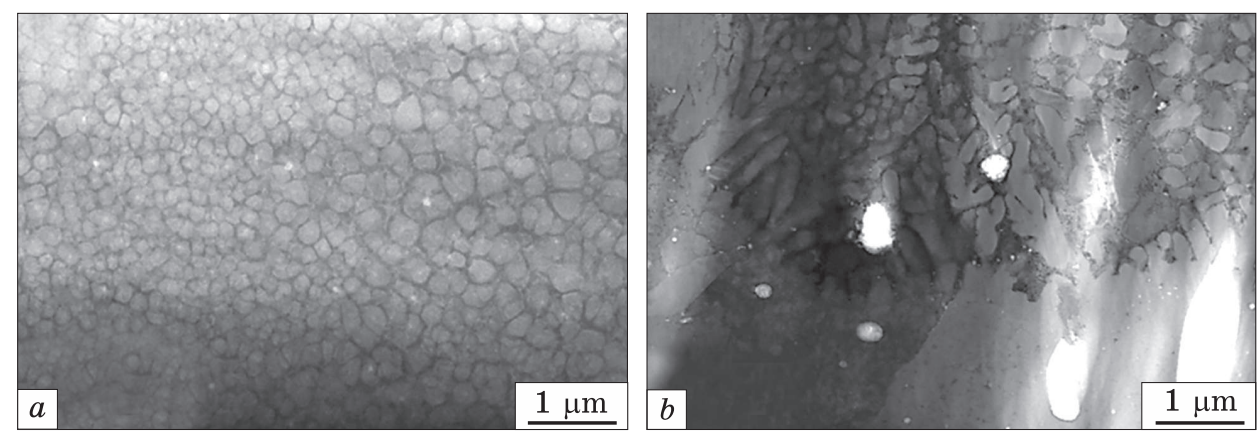

Fig. 25. CTEM images for the structure of the electroexplosive coating of the $\mathrm{ZnO}-\mathrm{Ag}$ system: $a$ - crystallization cells; $b$ - the transition region from the layer of electroexplosive coating, not affected by EBT in the volume of the copper electrical contact
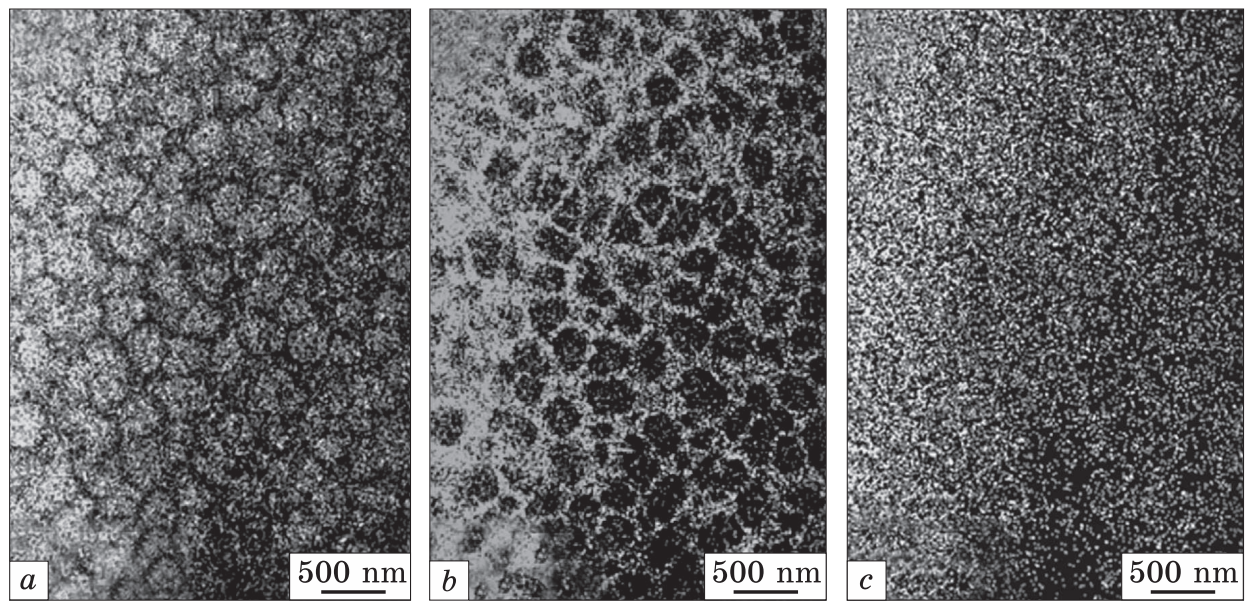

\begin{tabular}{|l|l|l|l|l|l|}
\hline Element & $E, \mathrm{keV}$ & Mass, \% & Counts & Error, \% & Atom, \% \\
\hline $\mathrm{Ag}(\mathrm{L})$ & 2.984 & 41.33 & 110668.01 & 0.01 & 55.14 \\
$\mathrm{Zn}(\mathrm{K})$ & 8.63 & 38.97 & 56755.73 & 0.01 & 30.63 \\
$\mathrm{O}(\mathrm{K})$ & 0.525 & 1.41 & 8254.66 & 0.03 & 13.86 \\
$\mathrm{Cu}(\mathrm{K})$ & 8.04 & 0.29 & 713.41 & 0.34 & 0.37 \\
Total & & 100 & & & 100 \\
\hline
\end{tabular}

Fig. 26. Images of the structure of the electric explosion coating of the $\mathrm{ZnO}-\mathrm{Ag}$ system. The table shows the elemental composition in the sample. Here, $a-c-$ images obtained in the characteristic x-ray emissions of $\mathrm{Ag}, \mathrm{Zn}$, and $\mathrm{O}$ atoms, respectively

the foils. The results presented in Fig. 24 show that $\mathrm{ZnO}$ particles are located both at the interfaces of silver plates and in the volume of silver plates. In the first case, the particles have sizes of $60-80 \mathrm{~nm}$, and in the second, of $10-20 \mathrm{~nm}$. 

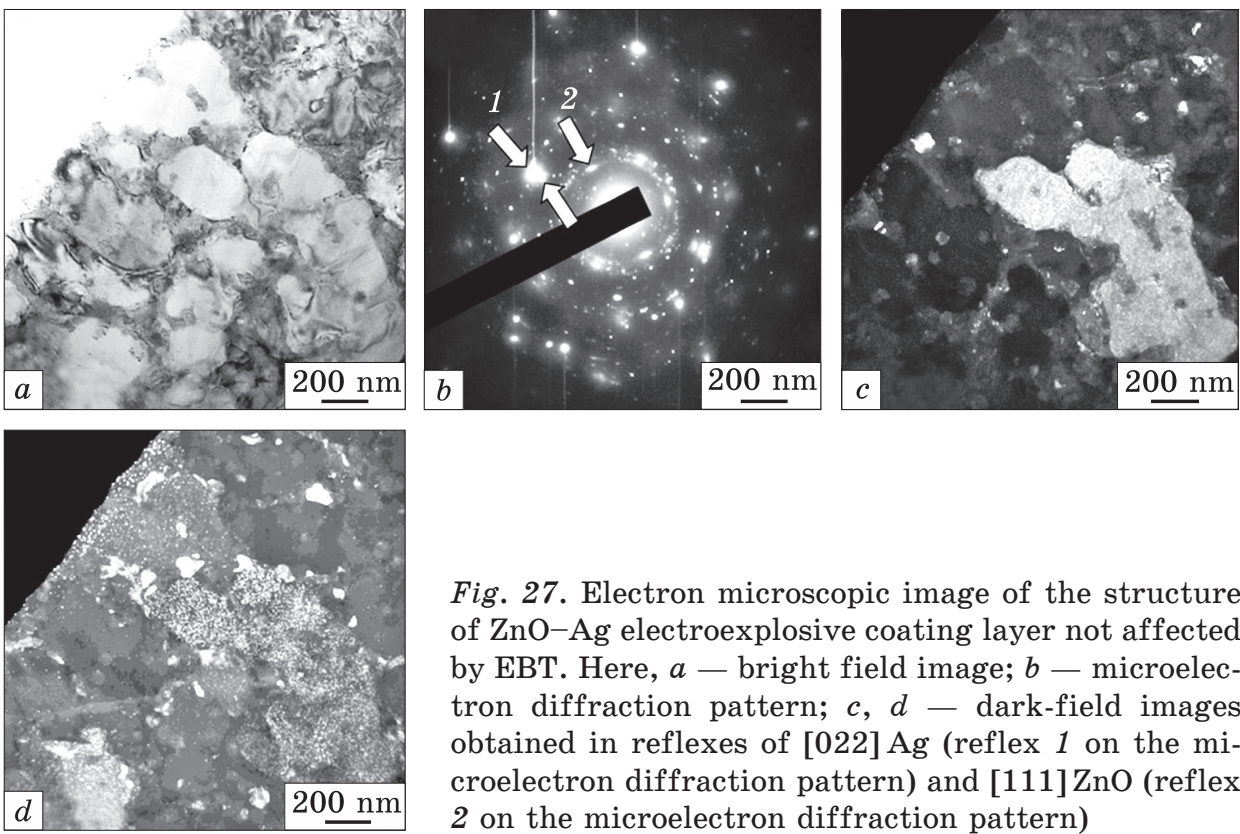

Fig. 27. Electron microscopic image of the structure of $\mathrm{ZnO}-\mathrm{Ag}$ electroexplosive coating layer not affected by EBT. Here, $a$ - bright field image; $b-$ microelectron diffraction pattern; $c, d$ - dark-field images obtained in reflexes of [022] Ag (reflex 1 on the microelectron diffraction pattern) and [111] ZnO (reflex 2 on the microelectron diffraction pattern)

The layer of electroexplosive coating not affected by EBT (layer 2 in Fig. 19). By means of transmission electron microscopy, it was found that the $\mathrm{ZnO}-\mathrm{Ag}$ electroexplosive coating not affected by EBT obtained at the copper electrical contact has the structure of high-speed cellular crystallization (Fig. 25, a). The cells have a rounded shape. The cell sizes vary from $250 \mathrm{~nm}$ to $380 \mathrm{~nm}$.

Using x-ray microanalysis of thin foils, the relative content of zinc atoms in the volume of a layer with a cellular substructure is 22.8 at.\%; oxygen atoms 10.2 at. $\%$. The cell volume is enriched with silver atoms, zinc atoms are arranged in the form of interlayers separating crystallization cells, oxygen atoms are distributed almost uniformly in the volume of the studied layer (Fig. 26).

A characteristic image of the structure of cellular crystallization of an electric blasting layer not affected by EBT, revealed by bright-field and dark-field methods, is shown in Fig. 27.

The analysis of the microelectron diffraction pattern (Fig. 27, a) obtained from the foil plot shown in Fig. 27, $a$, allows us to conclude that the cells are formed by a silver-based solid solution (Fig. 27, c); interlayers of the second phase separating silver cells are formed by the $\mathrm{ZnO}$ phase. The dark-field images shown in Fig. 27, $c, d$ indicate that $\mathrm{ZnO}$ phase particles are present in the cell volume. Particles have a rounded shape, particle sizes vary from $5 \mathrm{~nm}$ to $10 \mathrm{~nm}$.

The boundary of the electroexplosive coating with a copper substrate (indicated by the arrow in Fig. 19). In the zone of contact of the 

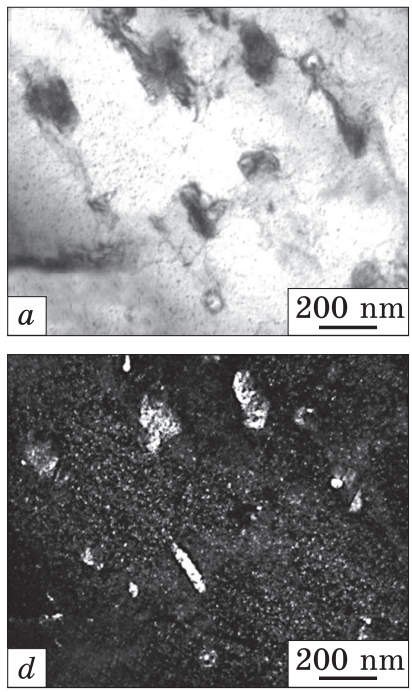
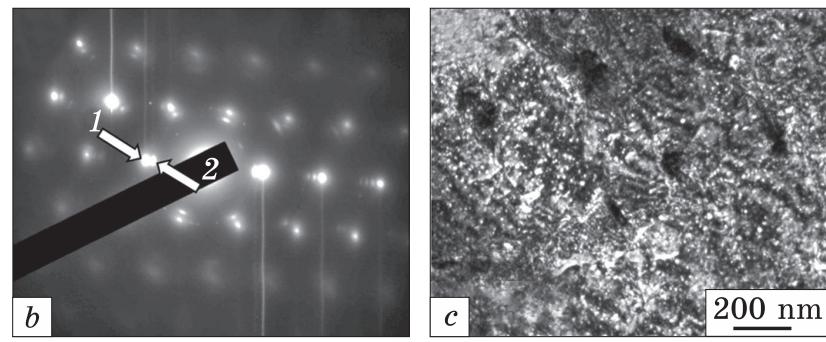

Fig. 28. Electron-microscopic image of the structure of the material located on the border of the electroexplosive coating with a copper substrate. Here, $a-$ bright field image; $b-$ microelectron diffraction pattern; $c$ and $d$ - dark-field images obtained in the reflections of [111] $\mathrm{Cu}(c)$ and [111] $\mathrm{Ag}(d)$; the arrows (c) indicate reflexes in which dark-field images 1 (c) and $2(d)$ were obtained

electroexplosive coating with the volume of the copper electrical contact, the structure of cellular crystallization transforms into a dendritic structure (Fig. 27, b). The relative content of zinc (oxygen) atoms averages 5.3 at. $\%(2.9$ at. $\%)$.

An electron microscopic image of the structure of the material located on the boundary of the electric explosion coating with the copper substrate is shown in Fig. 28.

Analysing the results presented in Fig. 28, $a$, it can be noted that two morphologically distinguishable types of particles of the second phase are present in the grains of a solid solution based on copper. Firstly, lamellar (globular) particles that form lines. The sizes of such particles are $80 \times 100 \mathrm{~nm}$. Secondly, round-shaped particles located randomly in the volume of copper grain (Fig. 28, d). Particle sizes vary within the range of 5-10 $\mathrm{nm}$. It can be assumed that lamellar (globular) particles are $\mathrm{Ag}_{5} \mathrm{Zn}_{8}$, and round particles are silver.

\subsection{Properties of Electroerosion-Resistant Coatings of CuO-Ag and $\mathrm{ZnO}-\mathrm{Ag}$}

Investigations of electroexplosive coatings of the $\mathrm{ZnO}-\mathrm{Ag}$ system after EBT are confirmed by the results of x-ray diffraction analysis (Fig. 29).

Tests for wear resistance showed that the EES of the copper coating of the $\mathrm{CuO}-\mathrm{Ag}$ system is accompanied by an increase in the wear resistance of the modified layer by $\approx 3.3$ times; the friction coefficient enhances by $\approx 1.4$ times. The mechanical properties of the modified copper layer were characterized by nanohardness and Young's modulus. They were determined on transverse sections, indenting along a straight line 

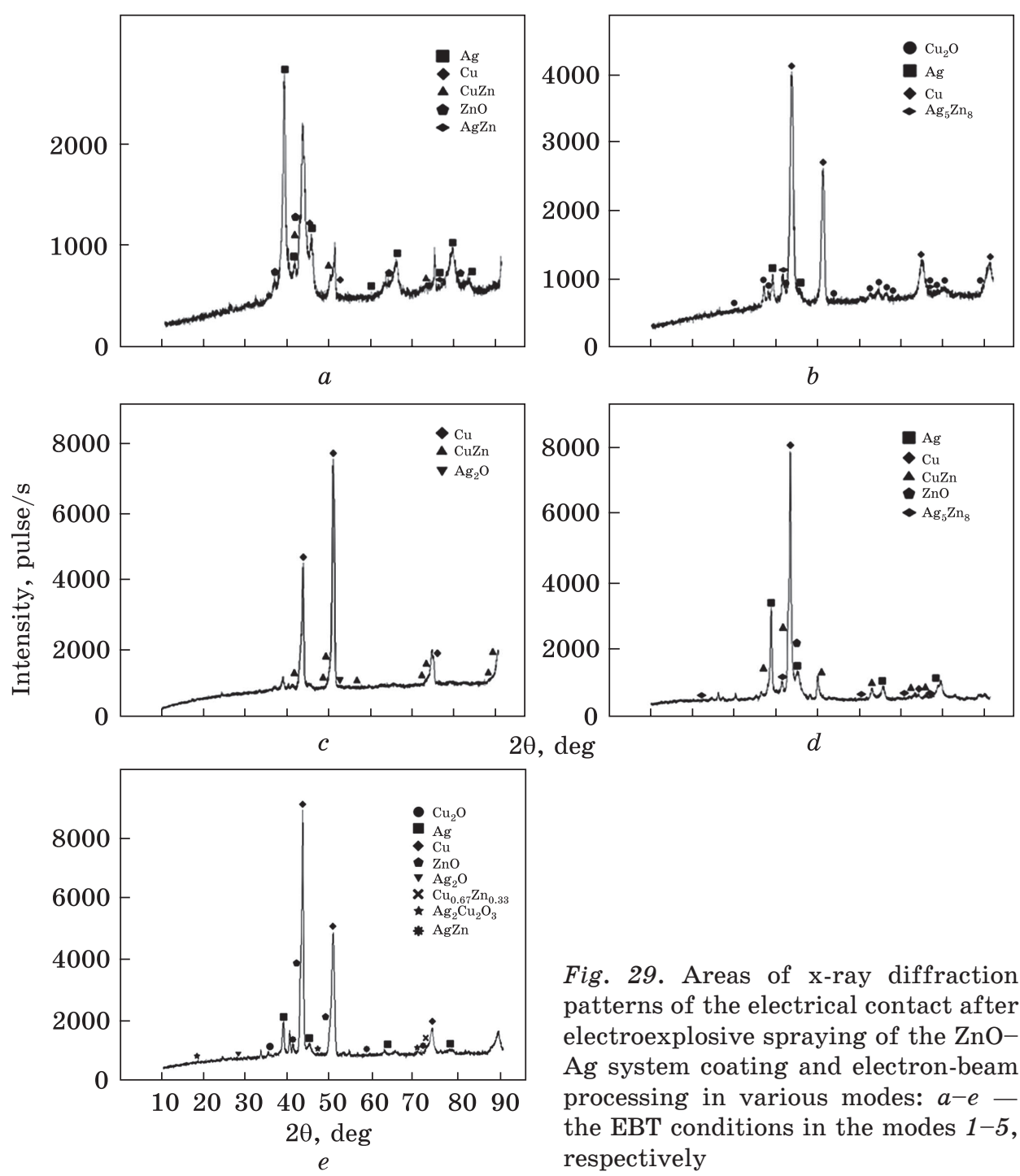

Fig. 29. Areas of x-ray diffraction patterns of the electrical contact after electroexplosive spraying of the $\mathrm{ZnO}-$ $\mathrm{Ag}$ system coating and electron-beam processing in various modes: $a-e-$ the EBT conditions in the modes $1-5$, respectively

parallel to the surface of the modification at a distance of $\approx 15 \mu \mathrm{m}$ from the surface of the treatment. The test results presented in Fig. 30 show that the nanohardness of the coating layer varies from $280 \mathrm{MPa}$ to $2290 \mathrm{MPa}$ with an average hardness of $866.5 \mathrm{MPa}$ (curve 1 in Fig. 30), which is more than 2 times the microhardness of annealed copper [71]. Young's modulus varies from $24.3 \mathrm{GPa}$ to $71.7 \mathrm{GPa}$ with an average modulus of $49.6 \mathrm{GPa}$ (curve 2 in Fig. 30). Note that the Young's modulus of annealed copper varies in the range (110-130) GPa [71].

Let us analyse the dependence of the contact resistance $(R)$ on the number of on/off cycles $(N)$ when testing the coatings of the $\mathrm{CuO}-\mathrm{Ag}$ 


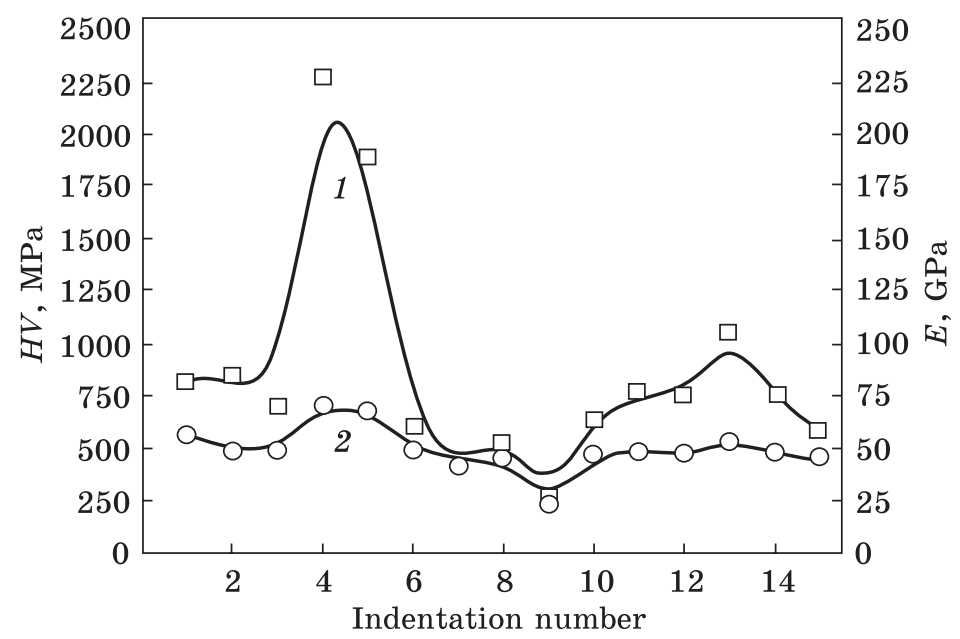

Fig. 30. Dependence of nanohardness (curve 1) and Young's modulus (curve 2) of the electric explosive coating of $\mathrm{CuO}-\mathrm{Ag}$ system on the indenter position on a line located at a depth of $\approx 15 \mu \mathrm{m}$ from the surface. See also Fig. 9 in [D.A. Romanov et al., Mater. Res. Express, 6: 085077 (2019)]; https://doi.org/10.1088/2053-1591/ab220a

system for electrical erosion resistance under conditions of arc erosion (Fig. 31). At the beginning of the experiment, the value of $R$ contacts is $11,7.5$, and $9.5 \mu \mathrm{Ohm}$ for phases $L_{1}, L_{2}$, and $L_{3}$, respectively. After the first on/off cycles are completed, the $\mathrm{R}$ begins to decrease from the initial linearly dependent values to new ones. They are as follow: for phase $L_{1}$, the value of $R$ is $6.3 \mu \mathrm{Ohm}$ at $N=3059$; for phase $L_{2}$, the value of $R$ is $7 \mu \mathrm{Ohm}$ at $N=2956$ and is the smallest among all phases; for phase $L_{3}$, the value of $R$ is $5.4 \mu \mathrm{Ohm}$ at $N=3211$. A gradual decrease in $R$ with a change in $N$ from 0 to 3211 indicates that the contacts are gradually burned in at this test site, as a result of which a stable surface roughness is created. In the next section of the curve, with an increase in $N$, $R$ increases to the maximum values: for phase $L_{1}$, the value of $R=$ $=15.6 \mu \mathrm{Ohm}$ at $N=5015$; for phase $L_{2}$, the value of $R=13.3 \mu \mathrm{Ohm}$ at $N=5123$ and is the smallest; for phase $L_{3}$, the value $R=14.3 \mu \mathrm{Ohm}$ at $N=4967$. This indicates that at the present stage of the experiment, intense evaporation of the low-melting silver matrix begins under the influence of an electric arc. The contact surface is enriched with particles of $\mathrm{CuO}$ powder, which has a lower electrical conductivity $\left(10^{-8} \mathrm{~S} / \mathrm{m}\right)$ compared to silver $(62.5 \mathrm{MS} / \mathrm{m})$ [67]. For this reason, the contact resistance in this section of the graph increases. When the maximum values of $R$ are reached in all three phases with a further increase in $N$, the electrical resistance decreases again. This is because at $N \approx 5000$, due to the evaporation of silver, the contact surface is enriched to the maximum with refractory $\mathrm{CuO}$ particles with low electrical conductivity. 


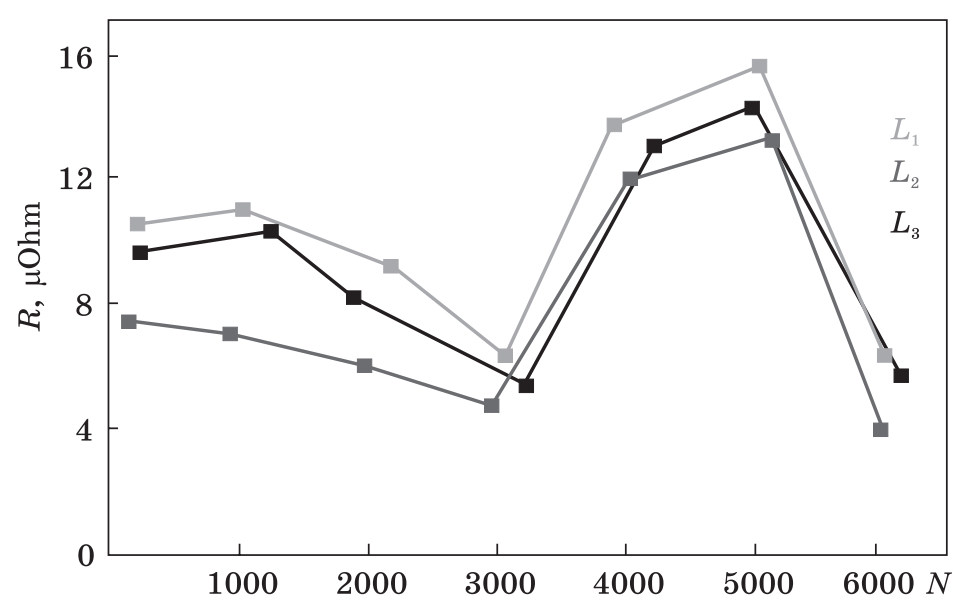

Fig. 31. The characteristic dependence of contact resistance $(R)$ on the number of on/off cycles $(N)$ when testing electric explosive coatings of the $\mathrm{CuO}-\mathrm{Ag}$ system for electrical discharge resistance under conditions of arc erosion. See also Fig. 4 in Ref. [60]

Upon reaching $N \approx 5000$, the mechanical accumulation of $\mathrm{CuO}$ particles on the contact surface occurs. As a result of this, the electrical resistance decreases again, namely, for phases $L_{1}$ and $L_{2}$, the values of $R$ are of $6.2 \mu \mathrm{Ohm}$ at $N=6023$ and of $4 \mu \mathrm{Ohm}$ at $N=5983$, respectively. For $L_{3}$, the value of $R=5.7 \mu \mathrm{Ohm}$ at $N=6122$. The tests performed showed that the formed coatings of the $\mathrm{CuO}-\mathrm{Ag}$ system satisfy the starter testing for switching wear resistance [72].

Thus, the increase in electrical resistance during tests of the electric blasting coatings of the $\mathrm{CuO}-\mathrm{Ag}$ system for switching wear resistance is caused by the evaporation of the low-melting silver matrix under the influence of an electric arc and the enrichment of the coating surface with $\mathrm{CuO}$ particles. The electrical contacts hardened by electric blasting coatings of the $\mathrm{CuO}-\mathrm{Ag}$ system are capable of mechanically cleaning the surface of $\mathrm{CuO}$ particles. The formed coatings of the $\mathrm{CuO}-$ $\mathrm{Ag}$ system satisfy the starter testing for switching wear resistance. Tests for electrical discharge resistance (Fig. 32) of coatings of the $\mathrm{CuO}-\mathrm{Ag}$ system after EBT showed that the destruction of the coating occurs after 3000 cycles of on/off. This is 2 times less in comparison with the electric explosive coatings of the $\mathrm{CuO}-\mathrm{Ag}$ system obtained in [68]. However, for low-current electrical contacts, these values are acceptable [72]. Electrical resistance (Fig. 32, $a$ ) during accelerated tests for electrical discharge resistance is in the range from 5.8 to $18 \mu \mathrm{Ohm}$, which is also acceptable for low-current electrical contacts.

In the process of testing the coatings, the influence of high temperatures leads to the melting of their surface and the formation of a 


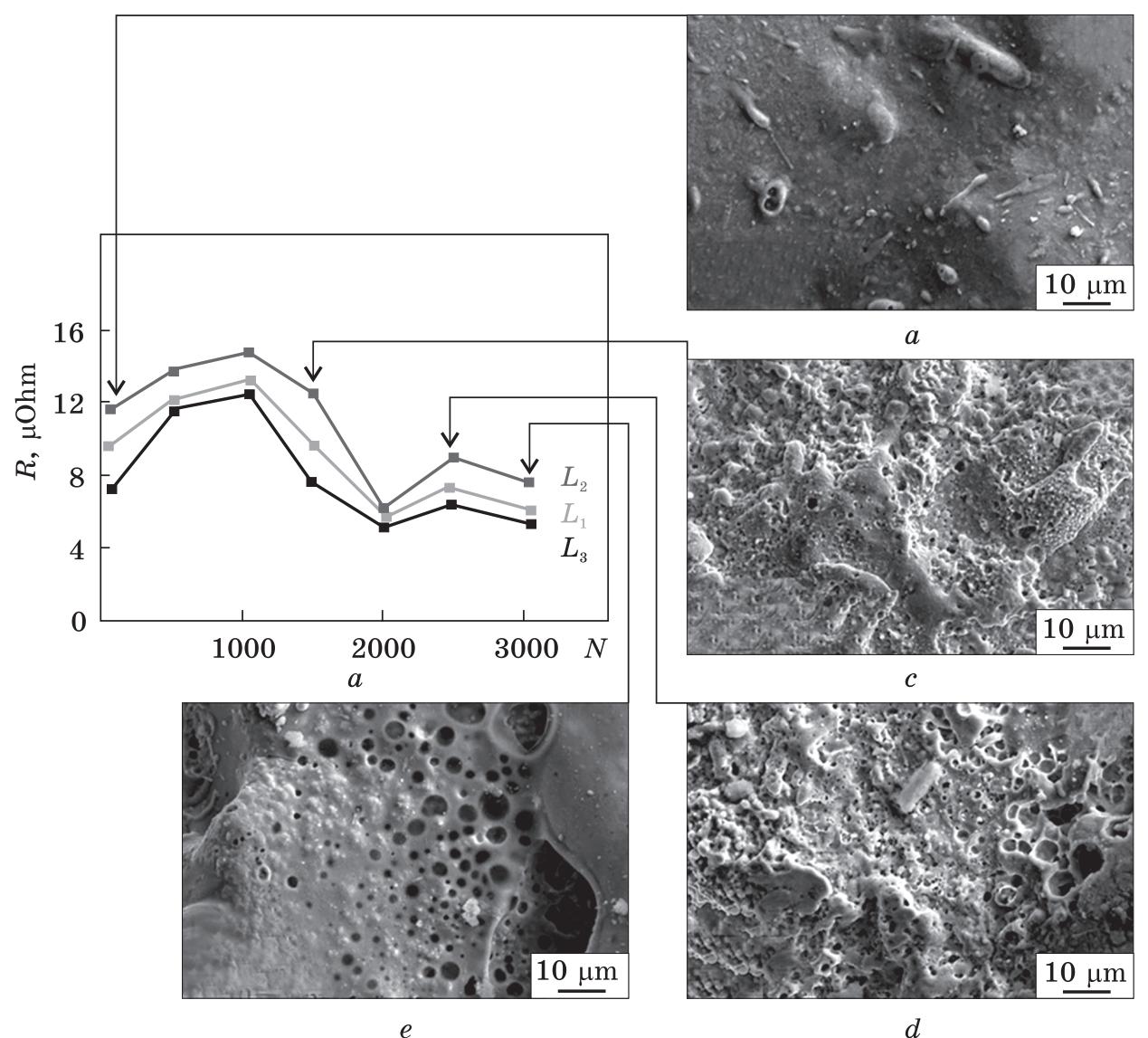

Fig. 32. The characteristic dependence of contact resistance $(R)$ on the number of on/off cycles $(N)$ when testing electric explosive coatings of the $\mathrm{CuO}-\mathrm{Ag}$ system for electrical discharge resistance under conditions of arc erosion. See also Fig. 4 in Ref. [60]

relief on it with a rough morphology (Fig. $32, b-d$ ). With increasing $N$, the number and size of craters resulting from the action of an electric arc on the coating surface increases. Moreover, silver, having a lower melting point, evaporates and copper oxides with a high melting point remain the main ones in the coating. The refractory component (copper oxides) forms a continuous matrix with silver particles measuring about a few micrometers. In local areas, degradation of the coating is observed up to the material of the copper substrate (Fig. 32, e). Probably, the refractory component plays the role of reducing the evaporation of lowmelting silver during the test process.

The results of the tests showed that the hardness of the electroexplosive coating of the $\mathrm{ZnO}-\mathrm{Ag}$ system varies from $750 \mathrm{MPa}$ to $2250 \mathrm{MPa}$ 


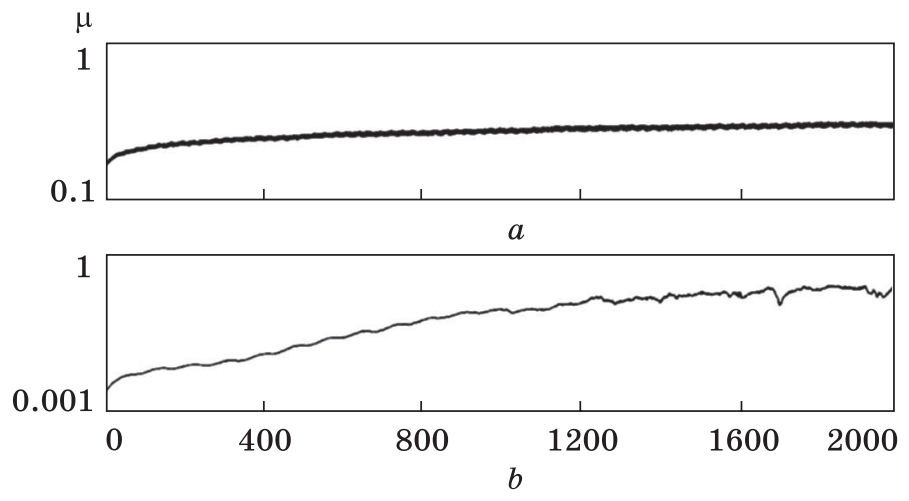

Fig. 33. Friction coefficient of the electroexplosive coating of the $\mathrm{ZnO}-\mathrm{Ag}$ system $v s$. the time of tribological tests: $a$ - sample without coating; $b$ - coated sample. See also Fig. 1 in [D. Romanov et al., J. Mater. Res. Technol., 8, No. 6: 5515 (2019)]; https://doi.org/10.1016/j.jmrt.2019.09.019

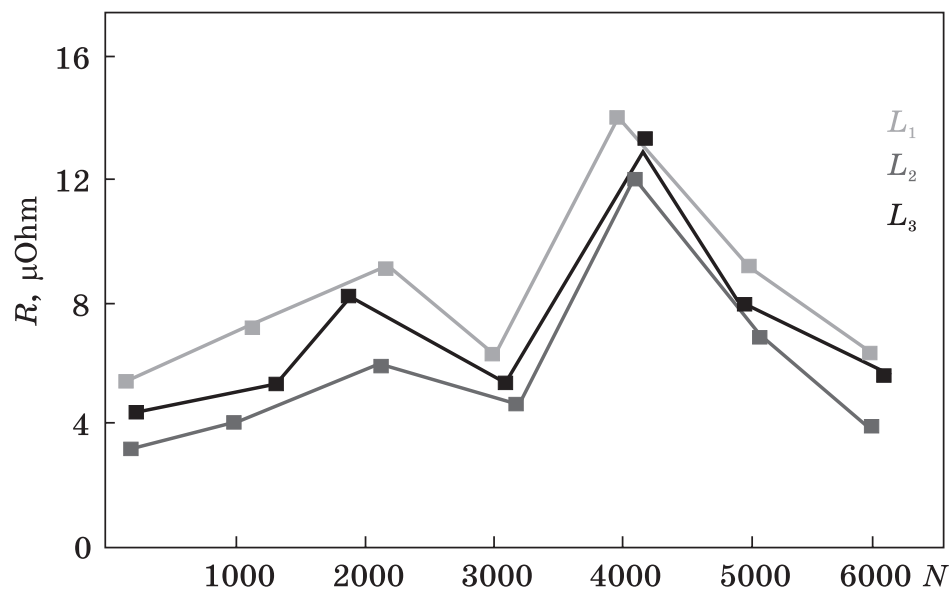

Fig. 34. The characteristic dependence of contact resistance $(R)$ on the number of on/off cycles $(N)$ when testing electric explosive coatings of the $\mathrm{ZnO}-\mathrm{Ag}$ system for electrical discharge resistance under conditions of arc erosion. See also Fig. 2 in [D. Romanov et al., J. Mater. Res. Technol., 8, No. 6: 5515 (2019)]; https://doi.org/ $10.1016 /$ j.jmrt.2019.09.019

with an average hardness of $1600 \mathrm{MPa}$, which is 3.8 times higher than the microhardness of annealed copper [71].

The Young's modulus of electroexplosive coating varies from $56.1 \mathrm{GPa}$ to $89.0 \mathrm{GPa}$ with an average modulus of $75.1 \mathrm{GPa}$. Note that the Young's modulus of annealed copper varies in the range of (110-130) GPa; the Young's modulus of silver is of $80 \mathrm{GPa}$ [71].

The EES of the copper coating of the $\mathrm{ZnO}-\mathrm{Ag}$ system is accompanied by a slight $(\approx 1.1$ times) increase in the wear resistance of the modi- 


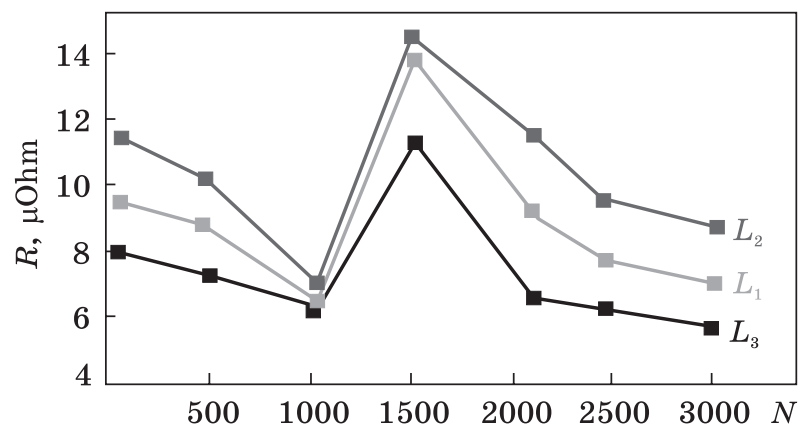

Fig. 35. Test results of electric explosion coatings of $\mathrm{ZnO}-\mathrm{Ag}$ after electron beam processing for electroerosion resistance in the conditions of arc erosion

Fig. 36. Dependence of nanohardness (curve 1) and Young's modulus (curve 2) of the modified layer on the indenter position on the line located at $\approx 15 \mu \mathrm{m}$ depth from the coating surface of $\mathrm{ZnO}-\mathrm{Ag}$ system

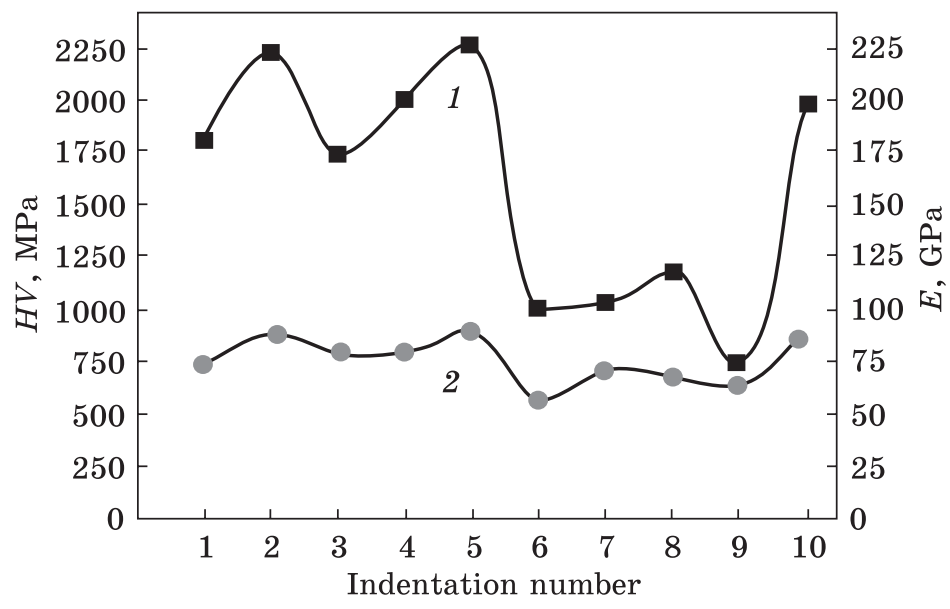

fied layer; the friction coefficient increases by $\approx 1.3$ times. Noteworthy is the change in the friction coefficient in the process of tribological testing (Fig. 33). Namely, at the initial stage of testing, the friction coefficient of the modified surface (Fig. 33, b) is significantly lower than the friction coefficient of the initial copper (Fig. 33,a). The latter may indicate that the hardened layer is thin and quickly loses its wearresistant properties.

Now, let us analyse the dependence of contact resistance $(R)$ on the number of on/off cycles $(N)$ when testing the coatings of the $\mathrm{ZnO}-\mathrm{Ag}$ system for electrical discharge resistance under conditions of arc erosion (Fig. 34). The initial resistance values for phases $L_{1}, L_{2}, L_{3}$ are of $5.6,3.2,5 \mu \mathrm{Ohm}$ with the number of on/off cycles of $134,152,213$, respectively. Subsequently, the resistance function increases. For phase $L_{1}$, the resistance increases from $5.6 \mu \mathrm{Ohm}$ to $9.2 \mu \Omega$ with the number of on/off cycles from 134 to 2178. For phase $L_{2}$, the resistance increases from $3.2 \mu \mathrm{Ohm}$ to $6 \mu \mathrm{Ohm}$ with the number of on/off cycles from 152 to 2134 . For phase $L_{3}$, the resistance increases from 5 to $8.2 \mu \mathrm{Ohm}$ with the number of on/off cycles from 213 to 1883. After that, the resistance 
decreases. For phase $L_{1}$, the resistance decreases to $6.3 \mu \mathrm{Ohm}$ with the number of cycles 3002 times. For phase $L_{2}$, the resistance decreases to $5.4 \mu \mathrm{Ohm}$ with the number of cycles 3145 times. For phase $L_{3}$, the resistance decreases to $7 \mu \Omega$ with the number of cycles 3211 times. Then the resistance index rises again and reaches its maximum value. For phase $L_{1}$, the resistance increases to $14.1 \mu \mathrm{Ohm}$ with the number of cycles 3990 times. For phase $L_{2}$, the resistance increases to $12 \mu \Omega$ with the number of cycles 4123 times. For phase $L_{3}$, the resistance increases to $13 \mu \Omega \mu$ with the number of cycles 4207 times. This indicates that at the present stage of the experiment, intensive evaporation of the fusible silver matrix begins under the influence of an electric arc. The contact surface is enriched with particles of $\mathrm{ZnO}$ powder, which has a lower electrical conductivity $\left(10^{-8} \mathrm{~S} / \mathrm{m}\right)$ compared to silver $(62.5 \mathrm{MS} / \mathrm{m})$ [67]. For this reason, the contact resistance in this section of the graph increases. At the end of the test, the resistance decreases again. For phase $L_{1}$, the resistance decreases to $6.3 \mu \mathrm{Ohm}$ with the number of cycles 5997 times. For phase $L_{2}$, the resistance decreases to $4 \mu \mathrm{Ohm}$ with the number of cycles 5983 times. For phase $L_{3}$, the resistance decreases to $5.7 \mu \mathrm{Ohm}$ with the number of cycles 6123 times. At the end of the test, the resistance values for phases $L_{1}, L_{2}, L_{3}$ are $6.3,4,5.7$ with the number of on/ off cycles 5997, 5983, 6123, respectively. The tests showed that the formed coatings of the $\mathrm{ZnO}-\mathrm{Ag}$ system satisfy the testing of starters for switching wear resistance [72].

The increase in electrical resistance during testing of $\mathrm{ZnO}-\mathrm{Ag}$ system electroexplosive coatings for switching wear resistance is caused by evaporation of a low-melting silver matrix under the influence of an electric arc and enrichment of the coating surface with $\mathrm{ZnO}$ particles. Electrical contacts hardened by $\mathrm{ZnO}-\mathrm{Ag}$ electroexplosive coatings are capable of mechanically cleaning the surface of $\mathrm{ZnO}$ particles. The formed coatings of the $\mathrm{ZnO}-\mathrm{Ag}$ system satisfy the starter testing for switching wear resistance.

Tests for electroerosive resistance (Fig. 35) of $\mathrm{ZnO}-\mathrm{Ag}$ system coatings after EBT showed that the destruction of the EBT coating layer occurs after 3000 on/off cycles. This is 2 times less in comparison with the electric explosive coatings of the $\mathrm{CuO}-\mathrm{Ag}$ system obtained in Ref. [68]. However, for low-current electrical contacts, these values are acceptable [72]. Electrical resistance (Fig. 35) during accelerated electroerosion tests is in the range from 6.2 to $17 \mu \mathrm{Ohm}$, which is also acceptable for low-current electrical contacts.

Contacts of any type (grade) should ensure not only long-term operation without unacceptable overheating under normal conditions, but also the required thermal and electrodynamic resistance in the short circuit mode. Movable breakable contacts should also not be destroyed by the high temperature of the electric arc, which is formed when they 
open, and reliably close without welding and fusion when turned on for a short circuit. The operation of these electrical contacts consists of 4 stages: open state, short circuit, closed state and open, each of which affects the reliability of contacting. In the open state, the external medium acts on the electrical contact and, as a result, films form on their surface. In the closed state, when the contacts are pressed against each other and current flows through them, they heat up and deform; under some conditions, if the contacts overheat, welding may occur. When the contacts are closed and opened, then, bridging or discharge phenomena occur, accompanied by evaporation and transfer of the contact metal, which changes its surface. In addition, mechanical wear of the contacts as a result of impacts and sliding against each other is possible. All of the above requirements are met when testing the obtained coatings of the $\mathrm{ZnO}-\mathrm{Ag}$ system (Fig. 35).

The test results presented in Fig. 36 (curve 1) show that the nanohardness of the coating layer varies from 750 to $2250 \mathrm{MPa}$ with an average hardness of $1600 \mathrm{MPa}$, which is more than 3.8 times the microhardness of annealed copper [72]. Young's modulus varies from 56.1 to 89.0 GPa with an average modulus of $75.1 \mathrm{GPa}$ (Fig. 36, curve 2). Note that the Young's modulus of annealed copper varies in the range of (110-130) GPa, while the silver Young's modulus is $80 \mathrm{GPa}$ [72].

\section{Conclusions}

The EES of the surface of a copper sample coated with a $\mathrm{CuO}-\mathrm{Ag}$ system and subsequent EBT lead to an increase in the wear resistance of the modified layer by $\approx 3.3$ times; the friction coefficient increases by $\approx 1.4$ times. It was found that the microhardness of the formed coating is more than 2 times greater than the microhardness of annealed copper.

Combined processing is accompanied by the formation of a multilayer structure up to 40 microns thick. It was found that in the surface layer with a thickness of $\approx 30 \mu \mathrm{m}$, a high-speed cellular crystallization structure is formed, regardless of the distance to the surface of the modification. The cell size varies from $150 \mathrm{~nm}$ to $300 \mathrm{~nm}$. The cells are separated by interlayers of the second phase, the thickness of which varies from $10 \mathrm{~nm}$ to $70 \mathrm{~nm}$. Using x-ray microspectral analysis, it was found that the bulk of cells is formed by copper atoms; silver atoms are located mainly in the interlayers along the cell boundaries.

The impact of the electron beam leads to the decomposition of copper monoxide $\mathrm{CuO}$, which leads to the formation of oxides $\mathrm{Cu}_{2} \mathrm{O}, \mathrm{Cu}_{64} \mathrm{O}$. Copper oxides with sizes from 0.1 to 0.2 microns are located in the silver matrix of the electroexplosive coating. Changes in the parameters of the crystal lattice and coherent scattering regions of the phases formed in the coating depend on changes in the physicochemical parameters of 
the crystalline substance and the specific energy of its crystal lattice caused by the action of an electron beam.

The EES of the surface of a copper sample coated with a $\mathrm{ZnO}-\mathrm{Ag}$ system and subsequent EBT lead to an increase in the wear resistance of the modified layer by $\approx 1.1$ times; the friction coefficient increases by $\approx 1.3$ times. It was established that the nanosolid hardness of the sprayed coating is $\approx 3.8$ times greater than the hardness of annealed copper. The Young's modulus of the coating is $75.1 \mathrm{MPa}$, and the nanohardness is $1600 \mathrm{MPa}$.

It was revealed that the EES of a copper sample is accompanied by the formation of a multilayer structure up to $60 \mu \mathrm{m}$ thick. In the surface layer, a structure of high-speed cellular crystallization is formed, regardless of the distance to the surface of the modification. Cell size ranges from $150 \mathrm{~nm}$ to $400 \mathrm{~nm}$. The cells are separated by interlayers of the second phase, the thickness of which varies from $15 \mathrm{~nm}$ to $50 \mathrm{~nm}$. It is shown that the transition layer has a dendritic crystallization structure on the surface layer side and a plate type structure on the side of the thermal influence layer. Using x-ray microspectral analysis, it was found that the volume of the cells of the surface layer structure is enriched with silver atoms, zinc and oxygen atoms are located mainly in the interlayers along the cell boundaries.

The combined treatment, including electroexplosive deposition of the coating of the $\mathrm{ZnO}-\mathrm{Ag}$ system and its subsequent electron- beam treatment, leads to the formation of a multilayer coating consisting of four layers. These are the following layers: (1) a surface layer obtained by two-stage processing of EES + EBT; (2) the boundary between the surface layer of EES + EBT and the layer of EES not affected by EBT; (3) a layer of electroexplosive coating not affected by EBT; (4) the boundary of the electroexplosive coating with a copper substrate.

High-speed crystallization of the surface layer obtained by two- stage processing of EES + EBT is accompanied by the formation of a submicron net structure. The cell volume is formed by a silver-based solid solution. The $\mathrm{ZnO}$ phase is detected in the form of thin $(35-73 \mathrm{~nm})$ layers separating silver cells, as well as in the form of nanoscale $(5-10 \mathrm{~nm})$ particles located in the volume of silver cells. This layer has a highspeed cellular crystallization structure with a net size of $(250-380) \mathrm{nm}$. The cell volume is enriched with silver atoms, zinc atoms are located mainly in the interlayers separating crystallization cells, oxygen atoms are distributed almost uniformly in the volume of the studied layer. Reflections of silver and $\mathrm{ZnO}$ and $\mathrm{Ag}_{5} \mathrm{Zn}_{8}$ compounds were revealed. It was established that crystallization cells formed by a silver-based solid solution contain nanosize $(\approx 20 \mathrm{~nm})$ particles of the second phases. The cells are separated by extended interlayers, which also have a nanostructured structure and are formed by phases based on silver and zinc. 
By the method of x-ray diffraction analysis, it was revealed that the phase composition of this layer is formed by the phases $\mathrm{Ag}, \mathrm{ZnO}, \mathrm{Cu}$, $\mathrm{CuZn}, \mathrm{Ag}_{5} \mathrm{Zn}_{8}, \mathrm{Cu}_{2} \mathrm{O}, \mathrm{Ag}_{2} \mathrm{O}, \mathrm{Cu}_{0.67} \mathrm{Zn}_{0.33}$, and $\mathrm{AgZn}$. The percentage of phases varies depending on the processing regime of the electron beam.

In the region of the interface between the surface layer of EES + + EBT and the EES layer not affected by EBT, a plate-like structure is formed, particles of zinc monoxide in which are located mainly along the boundaries of silver plates.

The layer of electroexplosive coating, not affected by EBT, is formed by layers of zinc monoxide separating silver cells, which were formed as a result of high-speed crystallization of the melt by eutectic reaction; zinc monoxide particles located in the volume of silver cells formed as a result of decomposition of a solid solution of zinc monoxide in silver upon cooling of the material from the eutectic transformation temperature to room temperature.

The boundary of the electroexplosive coating with a copper substrate is formed by grains of a solid solution based on copper. Silver particles and $\mathrm{Ag}_{5} \mathrm{Zn}_{8}$ compounds were detected in the volume of grains.

Typical sizes of the first and second hierarchical levels of the structure were established, which under the used spraying conditions ranged from 2 to $5 \mathrm{~nm}$ and from 10 to $15 \mathrm{~nm}$, respectively. A mechanism is proposed for the formation of hierarchical levels of the structure of electric explosive coatings of the $\mathrm{CuO}-\mathrm{Ag}$ and $\mathrm{ZnO}-\mathrm{Ag}$ systems. At the coating/substrate interface, surface periodic structures with a wavelength of $3 \mathrm{~nm}$ on average were detected. They represent the residual surface nanorelief that arose after the end of the action of a pulsed plasma jet of electrical explosion products of conductors on the substrate and cooling of the surface.

Formed electroexplosive coatings of the $\mathrm{CuO}-\mathrm{Ag}$ and $\mathrm{ZnO}-\mathrm{Ag}$ systems after EBT satisfy the requirements for testing starters for switching wear resistance of high-current and low-current electrical contacts. The uses of such coatings can double the life of copper electrical contacts.

Acknowledgement. The present work was carried out within the framework of the Russian Science Foundation (RSF) project No. 20-7900141.

\section{References}

1.S.J. Baek, M.S. Kim, W.J. An, and J.H. Choi, Compos. Struct., 220: 179 (2019); https://doi.org/10.1016/j.compstruct.2019.03.081

2. B. Tayebani and D. Mostofinejad, Compos. Struct., 208: 75 (2019); https://doi.org/10.1016/j.conbuildmat.2019.02.172

3. H.D. Roh, S.Y. Lee, E. Jo, H. Kim, W. Ji, and Y.B. Park, Compos. Struct., 216: 142 (2019);

https://doi.org/10.1016/j.compstruct.2019.02.100 
4. Y. Zhang, T. Hang, M. Dong, Y. Wu, H. Ling, A. Hu, and M. Li, Thin Solid Films, 677: 39 (2019); https://doi.org/10.1016/j.tsf.2019.03.012

5. Y. Zhu, Y. Xu, K. Li, X. Wang, G. Liu, and Y. Huang, Measurement, 138: 8 (2019); https://doi.org/10.1016/j.measurement.2019.02.035

6. Y.I. Kim, S. An, M.W. Kim, H.S. Jo, T.G. Kim, M.T. Swihart, A.L. Yarin, and S.S. Yoon, J. Alloys Compd., 790: 1127 (2019); https://doi.org/10.1016/j.jallcom.2019.03.154

7. A. Das, T.R. Ashwin, and A. Barai, J. of Energy Storage, 22: 239 (2019); https://doi.org/10.1016/j.est.2019.02.017

8. A.G. Mohammed, G. Ozgur, and E. Sevkat, Cold Regions Sci. Technol., 160: 128 (2019); https://doi.org/10.1016/j.coldregions.2019.02.004

9. R. As5tacio, J.M. Gallardo, J. Cintas, J.M. Montes, F.G. Cuevas, L. Prakash, and Y. Torres, Int. J. Refract. Met. Hard Mater., 80: 259 (2019); https://doi.org/10.1016/j.ijrmhm.2019.02.002

10. D. Zhang, P. Yi, L. Peng, X. Lai, and J. Pu, Carbon, 145: 333 (2019); https://doi.org/10.1016/j.carbon.2019.01.050

11. D. Mombrú, M. Romero, R. Faccio, and A.W. Mombrú, J. of Mater. Sci.: Mater. Electron., 30: 5959 (2019); https://doi.org/10.1007/s10854-019-00895-z

12. A. Kazemzadeh, F. Ein-Mozaffari, and A. Lohi, Chem. Eng. Res. Des., 143: 226 (2019); https://doi.org/10.1016/j.cherd.2019.01.018

13. T. Zhao, Y. Iso, R. Ikeda, K. Okawa, and M. Takei, Flow Meas. and Instrum., 65: 90 (2019); https://doi.org/10.1016/j.flowmeasinst.2018.11.010

14. Z.M. Sun, Int. Mater. Rev., 56, No. 3: 143 (2011); https://doi.org/10.1179/1743280410Y.0000000001

15. L. Peng, Scr. Mater., 56, No. 9: 729 (2007); https://doi.org/10.1016/j.scriptamat.2007.01.027

16. P. Zhang, T.L. Ngai, A. Wang, and Z. Ye, Vacuum, 141: 235 (2017); https://doi.org/10.1016/j.vacuum.2017.04.023

17. M. Liu, J. Chen, H. Cui, X. Sun, S. Liu, and M. Xie, Mater. Lett., 213: 269 (2018); https://doi.org/10.1016/j.matlet.2017.11.038

18. J. Ding, W.B. Tian, and P. Zhang, J. Alloys Compd., 740: 669 (2018); https://doi.org/10.1016/j.jallcom.2018.01.015

19. H. Li, X. Wang, X. Guo, X. Yang, and S. Liang, Mater. Des., 114: 139 (2017); https://doi.org/10.1016/j.matdes.2016.10.056

20. N. Ray, B. Kempf, T. Mützel, L. Froyen, K. Vanmeensel, and J. Vleugels, Mater. Des., 85: 412 (2015); https://doi.org/10.1016/j.matdes.2015.07.006

21. N. Ray, B. Kempf, G. Wiehl, T. Mützel, F. Heringhaus, L. Froyen, K. Vanmeensel, and J. Vleugels, Mater. Des., 121: 261 (2017); https://doi.org/10.1016/j.matdes.2017.02.070

22. M.P. Afonin and A.V. Boiko, Powder Metall. Met. Ceram., 44: 84 (2005); https://doi.org/10.1007/s11106-005-0061-y

23. E. Vinaricky and V. Behrens, Electrical Contacts, Proceedings of the Annual Holm Conference on Electrical Contacts (1998). 
24. V. Behrens, Th. Honig, A. Kraus, E. Mahle, R. Michal, and K.E. Saeger, Contacts, Proceedings of the Annual Holm Conference on Electrical Contacts (1995).

25. Y.-L. Chen, C.-F. Yang, J.-W. Yeh, S.-S. Hung, and S.-W. Lee, Metall. Mater. Trans. A, 36: 2441 (2005); https://doi.org/10.1007/s11661-005-0117-0

26. C.-P. Wu, D.-Q. Yi, W. Weng, S.-H. Li, J.-M. Zhou, Trans. Nonferrous Met. Soc. China, 26: 185 (2016); https://doi.org/10.1016/S1003-6326(16)64105-5

27. D. Wang, W. Tian, A. Ma, J. Ding, C. Wang, Y. You, P. Zhang, J. Chen, Y. Zhang, and Z. Sun, J. Alloys Compd., 784: 431 (2019); https://doi.org/10.1016/j.jallcom.2019.01.083

28. J. Ding, W. Tian, D. Wang, P. Zhang, J. Chen, Y. Zhang, and Z. Sun, Corros. Sci., 156: 147 (2019); https://doi.org/10.1016/j.corsci.2019.05.005

29. J. Ding, W. Tian, D. Wang, P. Zhang, J. Chen, Y. Zhang, and Z. Sun, J. Alloys Compd., 785: 1086 (2019); https://doi.org/10.1016/j.jallcom.2019.01.252

30. X. Wang, S. Wei, L. Xu, F. Fang, J. Li, K. Pan, and B. Peng, Mater. Charact., 153: 121 (2019); https://doi.org/10.1016/j.matchar.2019.04.017

31. B. Li, Z. Sun, G. Hou, P. Hu, and F. Yuan, J. Alloys Compd., 766: 204 (2018); https://doi.org/10.1016/j.jallcom.2018.06.338

32. Y. Guo, D. Guo, S. Wang, B. Gao, X. Wang, and Z. Shi, Mater. Express, 8, No. 6: 547 (2018); https://doi.org/10.1166/mex.2018.1462

33. X. Wen, F. Yuwen, Z. Ding, W. Zhang, R. Yao, and J. Lu, Tribology Int., 135: 269 (2019); https://doi.org/10.1016/j.triboint.2019.03.019

34. W. Huang, L. Kong, and X. Wang, Tribology Lett., 65: 17 (2017); https://doi.org/10.1007/s11249-016-0802-8

35. Y. Wang, G. Zhang, W. Wang, L. Si, and F. Liu, AIP Adv., 8, No. 11: 115020 (2018); https://doi.org/10.1063/1.5050327

36. Z. Lin, S. Fan, M. Liu, S. Liu, J.G. Li, J. Li, M. Xie, J. Chen, and X. Sun, J. Alloys Compd., 788: 163 (2019); https://doi.org/10.1016/j.jallcom.2019.02.085

37. Z. Lin, S. Liu, J.G. Li, J. Chen, M. Xie, X. Li, M. Zhang, Q. Zhu, D. Huo, and X. Sun, Mater. Des., 108: 640 (2016); https://doi.org/10.1016/j.matdes.2016.06.123

38. K. Zhang, G.Y. Qin, S.Y. Xu, J.X. Guo, and G. Ma, Metall. Mater. Trans. A, 46: 880 (2015); https://doi.org/10.1007/s11661-014-2642-1

39. X. Zhang, Y. Zhang, B. Tian, Y. Jia, Y. Liu, K. Song, and A.A. Volinsky, Vacuum, 164: 361 (2019); https://doi.org/10.1016/j.vacuum.2019.03.054

40. X. Zhang, Y. Zhang, B. Tian, J. An, Z. Zhao, A.A. Volinsky, Y. Liu, and K. Song, Composites Part B, 160: 110 (2019); https://doi.org/10.1016/j.compositesb.2018.10.040

41. W.J. Li, W.Z. Shao, N. Xie, L. Zhang, Y.R. Li, M.S. Yang, B.A. Chen, Q. Zhang, Q. Wang, and L. Zhen, J. Alloys Compd., 743: 697 (2018);

https://doi.org/10.1016/j.jallcom.2018.01.326 
42. Y.X. Zhou, Y.L. Xue, and K. Zhou, Vacuum, 164: 390 (2019); https://doi.org/10.1016/j.vacuum.2019.03.052

43. S. Biyik, Acta Phys. Pol. A, 134, No. 1: 208 (2018); https://doi.org/10.12693/APhysPolA.134.208

44. K. Zhou, W.G. Chen, J.J. Wang, G.J. Yan, and Y.Q. Fu, Int. J. Refract Met. Hard Mater., 82: 91 (2019); https://doi.org/10.1016/j.ijrmhm.2019.03.026

45. D. Poljanec and M. Kalin, Wear, 426-427, Part B: 1163 (2019); https://doi.org/10.1016/j.wear.2019.01.002

46. M. Kalin and D. Poljanec, Tribology Int., 126: 192 (2018); https://doi.org/10.1016/j.triboint.2018.05.024

47. D. Poljanec, M. Kalin, and L. Kumar, Wear, 406-407: 75 (2018); https://doi.org/10.1016/j.wear.2018.03.022

48. M. Wu, B. Hou, S. Shu, A. Li, Q. Geng, H. Li, Y. Shi, M. Yang, S. Du, J.Q. Wang, S. Liao, N. Jiang, D. Dai, and C.T. Lin, Nanomaterials, 9, No. 4: 498 (2019); https://doi.org/10.3390/nano9040498

49. S. Li, B. Hou, D. Dai, S. Shu, M. Wu, A. Li, Y. Han, Z. Zhu, B. Chen, Y. Ding, Q. Zhang, Q. Wang, N. Jiang, and C.T. Lin, Materials, 11, No. 8: 1459 (2018); https://doi.org/10.3390/ma11081459

50. S. Li, A. Li, D. Dai, Y. Liu, Y. Wu, H. Bai, C.T. Lin, and N. Jiang, Gongneng Cailiao J. Funct. Mater., 48, 9 (2017).

51. A. Bahramian, M. Eyraud, S. Maria, F. Vacandio, T. Djenizian, and P. Knauth, Corrosion Sci., 149: 75 (2019); https://doi.org/10.1016/j.corsci.2018.12.026

52. A. Bahramian, M. Eyraud, F. Vacandio, and P. Knauth, Microelectron. Eng., 206: 25 (2019); https://doi.org/10.1016/j.mee.2018.12.008

53. A. Bahramian, M. Eyraud, F. Vacandio, and P. Knauth, Surf. Coat. Technol., 345: 40 (2018); https://doi.org/10.1016/j.surfcoat.2018.03.075

54. M. Tokarska and M. Orpel, Textile Res. J., 89, No. 6: 1073 (2019); https://doi.org/10.1177/0040517518763978

55. B.K. Singh, E. Jain, and V.V. Buwa, Chem. Eng. J., 358: 564 (2019); https://doi.org/10.1016/j.cej.2018.10.009

56. S. Park, H.S. Kil, D. Choi, S.K. Song, and S. Lee, J. Industrial Eng. Chem., 69: 449 (2019); https://doi.org/10.1016/j.jiec.2018.10.008

57. A.V. Batrakov, S.A. Onischenko, I.K. Kurkan, V.V. Rostov, E.V. Yakovlev, E.V. Nefedtsev, and R.V. Tsygankov, 2018 28th International Symposium on Discharges and Electrical Insulation in Vacuum (ISDEIV) (2018), p. 77; https://doi.org/10.1109/DEIV.2018.8537014

58. A.V. Batrakov, S.A. Onischenko, I.K. Kurkan, V.V. Rostov, E.V. Yakovlev, E.V. Nefedtsev, and R.V. Tsygankov, 2018 20th International Symposium on High-Current Electronics (ISHCE) (2018), p. 126; https://doi.org/10.1109/ISHCE.2018.8521188

59. A.I. Sidorov, U.V. Yurina, G.R. Rakhmanova, M.N. Shinkarenko, O.A. Podsvirov, Y.K. Fedorov, and A.V. Nashchekin, J. Non-Cryst. Solids, 499: 278 (2018); https://doi.org/10.1016/j.jnoncrysol.2018.07.053

60. D.A. Romanov, S.V. Moskovskii, K.V. Sosnin, V.E. Gromov, and V.A. Bataev, Mater. Res. Express, 6, No. 5: 055042 (2019); https://doi.org/10.1088/2053-1591/ab0672 
61. V.V. Evstigneev, V.Ju. Filimonov, K.B. Koshelev, V.I. Jakovlev, and A.E. Zhakupova, Fundamental'nyye Problemy Sovremennogo Materialovedeniya, 2, No. 3: 98 (2005) (in Russian).

62. L. Ehngel and G. Klingele, Rastrovaya Ehlektronnaya Mikroskopiya. Razrushenie [Scanning Electron Microscopy. Destruction] (Moscow: Metallurgiya: 1986) (Russian translation).

63. M.M. Krishtal, I.S. Yasnikov, V.I. Polunin, A.M. Filatov, and A.G. Ulyanenkov, Skaniruyushchaya Ehlektronnaya Mikroskopiya i Rentgenospektral'nyy Analiz [Scanning Electron Microscopy and X-ray Spectral Analysis] (Moscow: Tehnosfera: 2009) (in Russian).

64. G.M. Moatimid, M.H. Obied Allah, and M.A. Hassan, Physics of Plasmas, 20, No. 10: 102111 (2013); https://doi.org/10.1063/1.4825146

65. M. Wang, W. Mei, and Y. Wang, Optics \& Laser Technology, 113: 123 (2019); https://doi.org/10.1016/j.optlastec.2018.12.007

66. C. Mallick, M. Bandyopadhyay, and R. Kumar, Review of Scientific Instruments, 89, No. 12: 125112 (2018); https://doi.org/10.1063/1.5048292

67. R. Venkata Krishna Rao, K. Venkata Abhinav, P.S. Karthik, and S.P. Singh, RSC Adv., 5: 77760 (2019); https://doi.org/10.1039/C5RA12013F

68. D.A. Romanov, S.V. Moskovskii, A.M. Glezer, V.E. Gromov, and K.V. Sosnin, Bull. RAS: Phys., 83: 1270 (2019); https://doi.org/10.3103/S1062873819100174

69. P.B. Hirsch, A. Howie, R.B. Nicholson, D.W. Pashley, and M.J. Whelan, Electron Microscopy of Thin Crystals (London: Butterwoths: 1965).

70. Yu.F. Ivanov, V.E. Gromov, N.A. Popova, S.V. Konovalov, and N.A. Koneva, Strukturno-Fazovye Sostoyaniya i Mehanizmy Uprochneniya Deformirovannoy Stali [Structural-Phase States and Mechanisms of Hardening of Strained Steel] (Novokuznetsk: Poligrafist: 2016) (in Russian).

71. A.P. Babichev, N.A. Babushkina, A.M. Bratkovskiy, Fizicheskie Velichiny: Spravochnik [Physical Quantities: A Handbook] (Eds. I.S. Grigoriev and E.Z. Meilikhova) (Moscow: Ehnergoatomizdat: 1991) (in Russian).

72. GOST 2933-83, Ispytanie na Mehanicheskuyu i Kommutatsionnuyu Iznosostojkost'. Apparaty Ehlektricheskie Nizkovol'tnye Metody Ispytaniy [Test for Mechanical and Switching Durability. Electrical Low-Voltage Test Methods] (Moscow: Izdatel'stvo Standartov: 1983) (in Russian).

Received 05.02.2021;

in final version, 18.06.2021

Д.А. Романов, В.В. Почетуха, В.Є. Громов, К.В. Соснін

Сибірський державний індустріальний університет, вул. Кірова, 42, 654007 Новокузнецьк, Російська Федерація

ФУНДАМЕНТАЛЬНІ ДОСЛІДЖЕННЯ СТРУКТУРИ ТА ВЛАСТИВОСТЕЙ ЕЛЕКТРОЕРОЗІЙНОСТІЙКИХ ПОКРИТТІВ НА МІДІ

На поверхні міді одержано електроерозійностійкі покриття систем $\mathrm{CuO}-\mathrm{Ag}$ i $\mathrm{ZnO}-\mathrm{Ag}$. Формування покриттів було спричинено обробленням поверхні міді плазмою, утвореною при електричному вибуху фолії срібла з суспендованим зразком оксиду міді або оксиду цинку. Після електропідривного напорошення 
було виконано електронно-пучкове оброблення покриттів. Досліджено нанотвердість, модуль Юнґа, зносостійкість, коефіцієнт тертя й електроерозійну стійкість утворених покриттів. Всі досліджені властивості перевищують властивості міді. Виконано дослідження електропідривних покриттів методами сканувальної електронної мікроскопії, просвітлювальної електронної мікроскопії й атомносилової мікроскопії. Досягнення високого рівня експлуатаційних властивостей електропідривних покриттів уможливилося завдяки їхньому наноструктуруванню. Структуру покриття утворено комірками високошвидкісної кристалізації. Розмір комірок змінюється у межах від 150 нм до 400 нм. Комірки розділено прошарками другої фази, товщина котрих змінюеться у межах 15-50 нм. Методом атомно-силової мікроскопії виявлено окремі частинки $\mathrm{ZnO}$ або $\mathrm{CuO}$ різної форми розміром у 10-15 нм, хаотично розташовані у срібній матриці, а також сферичні частинки $\mathrm{ZnO}$ або $\mathrm{CuO}$ розміром у 2-5 нм. Загальна товщина покриттів складає 60 мкм. Проведений комплекс досліджень дає змогу рекомендувати комплексне оброблення для зміцнення мідних контактів перемикачів потужних електричних мереж.

Ключові слова: композитне покриття, $\mathrm{CuO}-\mathrm{Ag}, \mathrm{ZnO}-\mathrm{Ag}$, мідні контактні дроти, електронно-пучкове оброблення, електропідривне напорошення, ерозійна стійкість, наноструктурування. 